University of Nebraska - Lincoln

DigitalCommons@University of Nebraska - Lincoln

Agronomy \& Horticulture -- Faculty Publications

Agronomy and Horticulture Department

2013

\title{
Nutrient partitioning and grain yield of TaNAM-RNAi wheat under abiotic stress
}

\author{
Mary J. Guttieri \\ University of Nebraska-Lincoln, mary.guttieri@usda.gov \\ Ricardo J. Stein \\ Ruhr Universität Bochum, ricardo.stein@rub.de \\ Brian M. Waters \\ University of Nebraska-Lincoln, bwaters2@unl.edu
}

Follow this and additional works at: https://digitalcommons.unl.edu/agronomyfacpub

Part of the Agricultural Science Commons, Agriculture Commons, Agronomy and Crop Sciences Commons, Botany Commons, Horticulture Commons, Other Plant Sciences Commons, and the Plant Biology Commons

Guttieri, Mary J.; Stein, Ricardo J.; and Waters, Brian M., "Nutrient partitioning and grain yield of TaNAM-RNAi wheat under abiotic stress" (2013). Agronomy \& Horticulture -- Faculty Publications. 736. https://digitalcommons.unl.edu/agronomyfacpub/736

This Article is brought to you for free and open access by the Agronomy and Horticulture Department at DigitalCommons@University of Nebraska - Lincoln. It has been accepted for inclusion in Agronomy \& Horticulture -Faculty Publications by an authorized administrator of DigitalCommons@University of Nebraska - Lincoln. 
Published in Plant and Soil: An International Journal on Plant-Soil Relationships 371 (2013), pp. 573-591;

doi: 10.1007/s11104-013-1713-1

Copyright (C) 2013 Springer Science+Business Media Dordrecht. Used by permission.

Submitted November 11, 2012; accepted April 3, 2013; published online April 21, 2013.

Supplemental materials follow the References.

\title{
Nutrient partitioning and grain yield of TaNAM-RNAi wheat under abiotic stress
}

\author{
Mary J. Guttieri, ${ }^{1}$ Ricardo J. Stein, ${ }^{1,2}$ and Brian M. Waters ${ }^{1}$ \\ 1. Department of Agronomy and Horticulture, University of Nebraska-Lincoln, Lincoln, NE 68583-0915, USA \\ 2. Present address: Lehrstuhl für Pflanzenphysiologie, Fakultät für Biologie und Biotechnologie, \\ Ruhr Universität Bochum, Bochum, Germany \\ Corresponding author - Brian M. Waters, email bwaters2@unl.edu
}

\begin{abstract}
Aims - Decreased expression of TaNAM genes by RNAi results in delayed senescence and decreased grain protein, iron, and zinc concentrations. Here, we determined whether NAM expression level alters onset of senescence under stress conditions, whether delayed senescence in the TaNAM-RNAi line resulted in improved tolerance to post-anthesis abiotic stress, and determined the effects of post-anthesis abiotic stress on $\mathrm{N}$ and mineral remobilization and partitioning to grain.

Methods - Greenhouse-grown WT and TaNAM-RNAi wheat were characterized in two studies: three levels of $\mathrm{N}$ fertility or water limitation during grain fill. Studies were conducted under both optimal and heat stress temperatures. Senescence onset was determined by monitoring flag leaf chlorophyll.

Results - Under optimal temperatures, TaNAM-RNAi plants had a yield advantage at lower N. TaNAM-RNAi plants had delayed senescence relative to the WT and lower grain protein and mineral concentrations, $\mathrm{N}$ remobilization efficiency, and partitioning of $\mathrm{N}$ and most minerals to grain.

Conclusions - Nutritional quality of TaNAM-RNAi grain was consistently lower than WT. Delayed senescence of TaNAM-RNAi plants provided a yield advantage under
\end{abstract}

optimal temperatures but not under water or heat stress. Discovery of specific NAM protein targets may allow separation of the delayed senescence and nutrient partitioning traits, which could be used for improvement of wheat.

Keywords: Wheat, grain mineral concentration, senescence, stress

\section{Introduction}

Grain yield and grain protein concentration are two principal targets of most hard wheat breeding programs. In addition to protein, staple crops also supply minerals for the human diet. The World Health Organization (WHO) reports that over 2 billion people are anemic (de Benoist et al. 2008), largely due to iron deficiency in their diets. In developing countries, $40 \%$ of preschool children are estimated to be anemic. Iron deficiency anemia leads to impaired cognitive and physical development and reduced work productivity, and is a contributing factor to $20 \%$ of maternal deaths. The 
WHO also estimates the global frequency of Zn deficiency to be $31 \%$ and extrapolates that the loss of disability-adjusted life years from $\mathrm{Zn}$ deficiency, globally, is over 28 million. Zinc deficiency contributes significantly to the mortality of children worldwide, although the problem is most severe in Africa, the Eastern Mediterranean, and southeast Asia (Black et al. 2008). Wheat grain protein, iron and zinc concentrations generally are positively correlated (Cakmak et al. 2004; Gomez-Becerra et al. 2010a, b; Morgounov et al. 2007; Murphy et al. 2011), which will facilitate simultaneous improvement of multiple minerals in wheat (Karami et al. 2009; Welch and Graham 2004).

Nitrogen (N) use by cereal crops to produce grain protein involves multiple processes, including uptake, assimilation, translocation, and remobilization. Grain N is supplied from $\mathrm{N}$ taken up post-anthesis and also from pre-anthesis stored $\mathrm{N}$ that is remobilized (Bogard et al. 2010; Kichey et al. 2007). A substantial percentage of the protein in wheat grain is supplied by amino acids remobilized from vegetative tissue (Barneix 2007; Gregersen et al. 2008; Masclaux-Daubresse et al. 2008) during leaf senescence (Hopkins et al. 2007). The proportion of grain $\mathrm{N}$ derived from remobilization of stored $\mathrm{N}$ has ranged from 45 to 95 \% (Bogard et al. 2010; Ercoli et al. 2008, 2010; Kichey et al. 2007; Masoni et al. 2007; Waters et al. 2009). Likewise, Fe and Zn are remobilized from vegetative tissues in several species (Drossopoulos et al. 1996; Hocking 1994; Hocking and Pate 1977; Miller et al. 1994; Waters and Grusak 2008).

During leaf senescence, photosynthetic capacity decreases, metabolism and gene expression change markedly, and the leaf transitions from a sink to source tissue. Chloroplasts and proteins are disassembled, and the resulting amino acids scavenged (Lim et al. 2007). A number of genes have decreased expression during senescence, while others are more highly or specifically expressed during leaf senescence (Gepstein et al. 2003), and are known as senescence associated genes (SAGs). Mineral element remobilization, which herein is defined as the net loss of stored mineral content from an organ over time, is directly or indirectly associated with expression of SAGs (Gregersen et al. 2008), although functionality, with respect to mineral remobilization, has been assigned to only a few SAGs (MasclauxDaubresse et al. 2008, 2010). Leaf senescence can be initiated prematurely by plant stresses such as heat stress, drought, and nutrient deficiency. Some SAGs are expressed under both natural and stressinduced senescence, while others are expressed exclusively during specific senescence conditions (Buchanan-Wollaston et al. 2005; Van der Graaff et al. 2006). Avoidance of leaf senescence during drought stress, a phenotype known as stay-green, is associated with grain yield in maize, wheat, and sorghum (Harris et al. 2007; Snape et al. 2007; Thomas and Howarth 2000; Zheng et al. 2009).

Correlations between onset of senescence and grain protein concentration (GPC) and between onset of senescence and grain yield vary depending on environmental conditions (Bogard et al. 2011). The relationship between senescence and grain protein concentration is particularly evident in the wheat Grain Protein Content (Gpc)-B1 QTL on chromosome 6BS (Kade et al. 2005; Uauy et al. 2006a). Using mapbased cloning in a Triticum turgidum ssp. durum $\times$ T. turgidum ssp. diccocoides genotype, the Gpc-B1 QTL was identified as a NAC transcription factor, NAM$B 1$ (Uauy et al. 2006b). Members of the large family of NAC transcription factors have roles in plant development, abiotic stress, and biotic stress responses (reviewed by (Nakashima et al. 2012)). Overexpression of some NAC family genes have resulted in improved tolerance to abiotic stresses (Mao et al. 2012; Xue et al. 2011). Alleles containing a 1-bp insertion or a deletion of NAM-B1 predominate in cultivated wheat varieties (Asplund et al. 2010; Uauy et al. 2006b). Introgression of a functional Gpc-B1 allele increased grain protein concentration (Brevis et al. 2010) as well as grain Fe, Mn, and Zn concentration (Distelfeld et al. 2007). Conversely, decreased expression of the four endogenous wheat NAM-B1 family genes TaNAM-A1, D1, B2, and D2, (which were upregulated in flag leaves rapidly after anthesis), using a TaNAM-RNA interference (RNAi) construct, resulted in delayed senescence (Uauy et al. 2006b). Therefore, these genes likely act early in the regulatory pathway of developmental senescence. TaNAM-RNAi also decreased $\mathrm{N}$ remobilization and $\mathrm{N}$ partitioning to developing grain (Waters et al. 2009). Although grain weight was not significantly affected by TaNAM-RNAi expression, protein, iron, and zinc concentrations were significantly lower in grain from TaNAM-RNAi plants (Uauy et al. 2006b; Waters et al. 2009).

The previous studies that characterized the senescence effects of the TaNAM-RNAi on wheat plants 
were performed under optimal conditions of temperature, available moisture, and N-sufficiency. However, the effects of the TaNAM-RNAi trait have not been evaluated in plants grown under stress conditions. Additionally, since $\mathrm{N}$ supply substantially influences N efficiency (Górny et al. 2011), experiments evaluating the effects of the TaNAM-RNAi trait on $\mathrm{N}$ dynamics under sub-optimal $\mathrm{N}$ supply were needed. Moreover, mineral uptake is intimately connected with nutrient and moisture availability, as well as climatic conditions (Karami et al. 2009). For example, $\mathrm{N}$ availability has been shown to have effects on uptake and translocation of other grain minerals. Iron and zinc concentration of wheat grain, and $\mathrm{Zn}$ and Fe uptake and remobilization were substantially increased by improved N fertility (Aciksoz et al. 2011; Cakmak et al. 2010; Erenoglu et al. 2010; Kutman et al. 2010, 2011a; $b$; Shi et al. 2010).

Efforts to improve the nutrient use efficiency of crop plants are motivated by economic factors (e.g. increasing fertilizer costs), and by recognition of detrimental environmental effects of excess fertilizer use. Genetic variation for grain protein concentration appears to be particularly associated with post-anthesis N uptake (Bogard et al. 2010). Genetic variability for $\mathrm{N}$ remobilization efficiency has been observed in wheat within existing varieties (Bogard et al. 2010; Kichey et al. 2007; Van Sanford and MacKown 1987), and alterations in $\mathrm{N}$ remobilization efficiency in the TaNAM-RNAi line (Waters et al. 2009) indicate that there are metabolic processes that could potentially be targeted to improve this trait. Next Generation Sequencing of the GPC-RNAi and WT transcriptomes 12 days after anthesis, when NAM gene expression was decreased by $35 \%$ relative to WT, revealed 691 genes that were differentially regulated by the NAM genes (Cantu et al. 2011), some of which may be involved with regulating senescence and $\mathrm{N}$ and mineral translocation to seeds.

Here, we address three primary objectives. The first objective was to determine whether expression level of NAM genes alters onset of senescence under stress conditions that induce premature senescence. A second objective was to determine whether delayed senescence in the TaNAM-RNAi line results in improved tolerance (in terms of yield) to post-anthesis abiotic stress. A third objective was to determine the effects of post-anthesis abiotic stress (heat, water, and low $\mathrm{N}$ stress) on $\mathrm{N}$ and mineral remobilization and partitioning to grain.

\section{Materials and methods}

\section{Plant materials and growth}

Seeds of WT hexaploid spring wheat cv. 'Bobwhite' and the TaNAM-RNAi line were generously provided by Jorge Dubcovsky (University of California-Davis, Davis, CA, USA). Six seeds were planted per pot ( 3 seeds TaNAM-RNAi, 3 seeds WT) in $2.2 \mathrm{~kg} \mathrm{1:1} \mathrm{soil:} \mathrm{sand} \mathrm{in} \mathrm{clay} \mathrm{containers} 15 \mathrm{~cm}$ deep, $16 \mathrm{~cm}$ diameter at the top and $10 \mathrm{~cm}$ diameter at the bottom. Seedlings were later thinned to 2 plants of each line, for a total of 4 plants per pot. Treatments were assigned randomly to pots. At least 6 pots (12 plants of each genotype) were assigned to each treatment. Plants were grown in a greenhouse with supplemental lighting to provide a $16 \mathrm{~h}$ photoperiod.

Two studies were conducted, a fertility response study and a moisture stress study. The fertility response study was a factorial arrangement of a completely randomized design where the factors were genotype (WT, TaNAM-RNAi) and fertility treatment (3 levels). Fertility treatment levels were selected to represent full fertility and two levels of reduced fertility (moderate and severe), with the severe deficiency meant to induce premature senescence. All treatments in the fertility response study were well-watered. The moisture stress study was conducted as a factorial arrangement of a completely randomized design where the factors were genotype (WT, TaNAM-RNAi) and post-anthesis applied irrigation (moisture stress, well-watered). Plants in the moisture stress studies were fertilized at the highest rate used in the fertility studies. The studies were conducted in two environments. Environment 1 was a heat stress regime: day temperatures were set for $27-31{ }^{\circ} \mathrm{C}$, night temperatures at 21-24 ${ }^{\circ} \mathrm{C}$. Environment 2 was an optimal temperature regime: day temperatures were set for $18-24^{\circ} \mathrm{C}$, night temperatures for $13-18^{\circ} \mathrm{C}$.

Fertilization was supplied in a nutrient solution containing $0.5 \mathrm{mM} \mathrm{MgSO}_{4}, 1 \mathrm{mM} \mathrm{CaCl}, 0.1 \mathrm{mM}$ $\mathrm{NaH}_{2} \mathrm{PO}_{4}$, with $\mathrm{N}$ supplied as $\mathrm{KNO}_{3}$ at rates indicated below. Fertility treatments were initiated with a uniform base application 33 and 28 DAP in environments 1 and 2, respectively. Three differential fertility treatments were applied $(0,43.75$, or $87.5 \mathrm{mg}$ N per application) at 4-6, 11-13, and 16$20 \mathrm{~d}$ after the base application. Fertility treatments were completed 1 and 4 days prior to anthesis of 
the first plants in environments 1 and 2, respectively. Total $\mathrm{N}$ applied to the three treatments was $35 \mathrm{mg}, 166 \mathrm{mg}$, and $298 \mathrm{mg} \mathrm{pot}^{-1}$. Soil test data indicated that potting soil provided an additional $35 \mathrm{mg}$ of $\mathrm{N}$ to each pot, and as there were four plants per plot, available $\mathrm{N}$ was estimated as a combined (soil + applied) total of 17.5, 61.25, and $105 \mathrm{mg} N$ per plant. Containers in the fertility studies received $250 \mathrm{ml}$ water each $2 \mathrm{~d}$ from anthesis until the conclusion the experiment. For the moisture stress study, differential irrigation treatments were applied to plants beginning with the first irrigation during anthesis. Two treatments (moisture stress $=150 \mathrm{ml}$ water, well-watered $=250 \mathrm{ml}$ water) were applied each $2 \mathrm{~d}$ from anthesis until the conclusion the experiment.

\section{Tissue sampling}

Above ground tissue of 6 plants of each genotype and treatment were harvested at anthesis. At maturity, spikes and vegetative tissues were harvested separately from at least six plants of each genotype and treatment. Plant samples were dried in a drying oven at $60 \mathrm{C}$ for at least $48 \mathrm{~h}$. Grains were removed from spikes, then spikes were pooled with vegetative tissues from the same plant. Spikes less grain are considered vegetative tissues for the purposes of this study. Tiller number, plant and seed dry weight and kernel number were recorded. Tillers were ground in a Wiley mill, while seeds were ground in a coffee grinder for analysis of mineral composition and $\mathrm{N}$ analysis. Mineral concentrations were determined by ICP-MS following digestion of tissues in nitric acid/hydrogen peroxide as described previously (Waters and Grusak 2008). N was determined by combustion analyses using a Costech Analytical ECS 4010 (Costech Analytical Technologies, Valencia, CA). Protein concentration was calculated as $\mathrm{N} \times 5.7$.

Senescence was monitored by the decrease in relative leaf chlorophyll of flag leaves using a handheld SPAD-502Plus chlorophyll meter (Konica Minolta, Japan). Means of 10 readings were recorded from 6 plants for each treatment and genotype through 42 days after anthesis (DAA) in the heat stress environment and through 38 DAA in optimal temperature environment in the fertility studies, and through 30 DAA in the irrigation studies.

\section{Real-time RT-PCR}

Total RNA was extracted from node, peduncle, lower leaf, stem, and spike tissues at anthesis, and from node, rachis, peduncle, senescing lower leaf, green lower leaf, flag leaf, florets + grain, and stem tissues at 14 DAA using the Aurum Total RNA Fatty and Fibrous Tissue kit (Bio-Rad, Hercules, CA, USA). RNA quality and concentration was determined by UV spectrophotometry. One $\mu \mathrm{g}$ of DNase-treated RNA (RNase-free DNase I, New England Biolabs, Ipswich, MA, USA) was used for cDNA synthesis, using the High Capacity cDNA Reverse Transcription kit (ABI, Foster City, CA, USA) with random hexamers at $2.5 \mu \mathrm{M}$ final concentration. Real-time RT-PCR primers and conditions were based on those of a previous study (Uauy et al. 2006b). cDNA corresponding to $50 \mathrm{ng}$ of total RNA was used in a $15 \mu \mathrm{L}$ real-time PCR reaction performed in a MyIQ (Bio-Rad, Hercules, CA, USA) thermal cycler using SYBR GreenER qPCR SuperMix (Invitrogen Technology, Carlsbad, CA, USA) and $0.2 \mu \mathrm{M}$ of gene-specific primers (see below). The following standard thermal profile was used for all PCRs: $50{ }^{\circ} \mathrm{C}$ for $2 \mathrm{~min}, 95^{\circ} \mathrm{C}$ for $8 \mathrm{~min} ; 40$ cycles of $95{ }^{\circ} \mathrm{C}$ for $15 \mathrm{~s}$ and $60{ }^{\circ} \mathrm{C}$ for $30 \mathrm{~s}$. At the end of each reaction, a dissociation curve was performed to ensure primer specificity. The $\mathrm{Ct}$ values for all genes were calculated using BioRad IQ5 System Software version 2.0 (Bio-Rad, Hercules, CA, USA) and normalized to the $\mathrm{Ct}$ value of actin using the equation $\mathrm{Y}=2^{-\Delta C t}$, where $\Delta C t=C t_{U B Q 10}-C t_{\text {target gene }}$. The PCR efficiency from the exponential phase (E) was calculated for each individual amplification plot using the equation $(1+E)=10^{\text {slope }}$ calculated by the LinRegPCR program (Ramakers et al. 2003). PCR efficiency ranged from 97 to $99.5 \%$, with correlation coefficient $\left(\mathrm{r}^{2}\right)$ ranging from 0.98 to 1.0. The calculated PCR efficiency was then used to normalize each obtained $\mathrm{Ct}$ value. The primer sequences used for actin, NAM-A1, $-D 1,-B 2$, and $-D 2$ were described previously (Uauy et al. 2006b).

\section{Calculations}

Vegetative $\mathrm{N}$ content (per plant): $\mathrm{N}$ concentration $\left(\mathrm{mg} \mathrm{g}^{-1}\right) \times$ Vegetative tissue dry weight $\left(\right.$ g plant $\left.^{-1}\right)$ Harvest index (HI): Seed yield $(\mathrm{dw}) /($ seed yield + above ground vegetative tissue dry weight)

Nutrient Harvest index: Seed nutrient content 
Figure 1. Expression of NAM genes in wild-type wheat tissues, normalized to actin. Inset shows NAM-A1, $-D 1$, $D 2$, and $-B 2$ quantification by real-time RT-PCR at anthesis. The main panel shows expression of the same genes at 14 DAA.

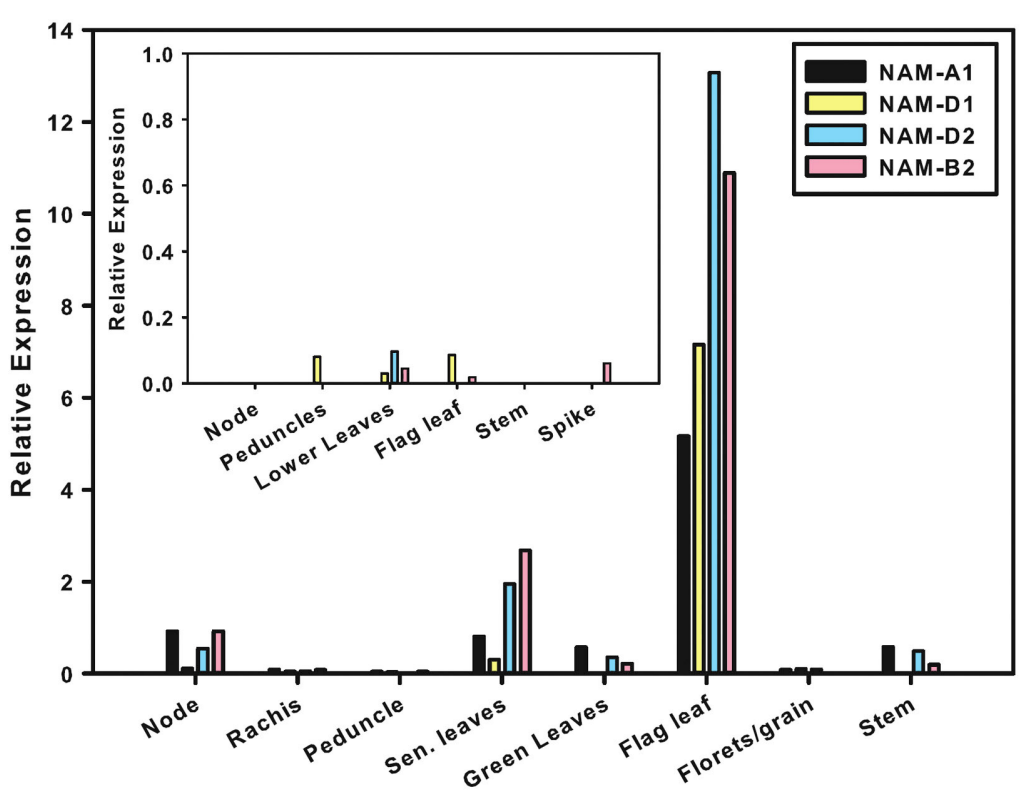

(mg plant ${ }^{-1}$ )/Whole plant nutrient content (mg plant $^{-1}$ )

Net Remobilization: Plant mineral or $\mathrm{N}$ content at anthesis (mg spike $\left.{ }^{-1}\right)$ - Vegetative content at maturity (mg spike $\left.{ }^{-1}\right)$

Remobilization Efficiency: $100 \times$ Net remobilization/Plant mineral or $\mathrm{N}$ content at anthesis

Post-anthesis N Accumulation (PANA): Whole plant content at maturity $\left(\mathrm{mg} \mathrm{plant}^{-1}\right)$ - Plant content at anthesis (mg plant ${ }^{-1}$ )

Normalized Partitioning Quotient (PQ): 100 $x($ Nutrient harvest index/Harvest index)/Experimental Mean

\section{Statistical analysis}

Data were analyzed by analysis of variance using PROC GLIMMIX in SAS. Growth in each environment was conducted for one season; therefore tests of environment effects could not be made. Residual variances in the two environments were highly heterogenous $(p<0.001)$ in both the fertility and moisture stress studies for the key traits of plant DW, seed DW, and seed number. Therefore, environments could not be combined for statistical analysis and separate analyses were conducted of each study in each environment. Main effects of treatment and linear and quadratic effects of fertility rate, and their interactions with the main effect of genotype, were tested using Type I sums of squares. Least squares adjusted means are presented in tables, and mean differences (net remobilization, PANA) were estimated using LSMESTIMATE in PROC GLM.

\section{Results}

\section{Senescence effects of NAM expression}

In a previous study, wheat NAM genes were upregulated rapidly after anthesis, however, expression was quantified only in flag leaves (Uauy et al. 2006b). Since other tissues (i.e. spike, peduncle, lower leaves) also exhibit delayed monocarpic senescence in the TaNAM-RNAi line, we tested whether the NAM genes were expressed in other tissues in wild-type hexaploid spring wheat. By realtime RT-PCR, no or very little mRNA for NAM-A1, $-D 1,-D 2$, and $-B 2$ was detected in nodes, peduncles, green lower leaves, flag leaf, stem, or whole spike in pre-anthesis wheat plants (Figure 1, inset). In plants $14 \mathrm{~d}$ later, during grain fill, expression was still low in the rachis and florets + grain of the spike, the peduncle, stem, and green lower leaves. Expression of NAM-A1, $-D 1$, and $-B 2$ were slightly higher in green lower leaves, stem, and nodes, and moderately expressed in senescing lower leaves. High levels of expression were observed for all four NAM genes in flag leaf during grain fill.

SPAD meter readings of flag leaf chlorophyll were used to monitor senescence (Figure 2), and demonstrated the previously described phenotypic difference in timing of senescence onset between 

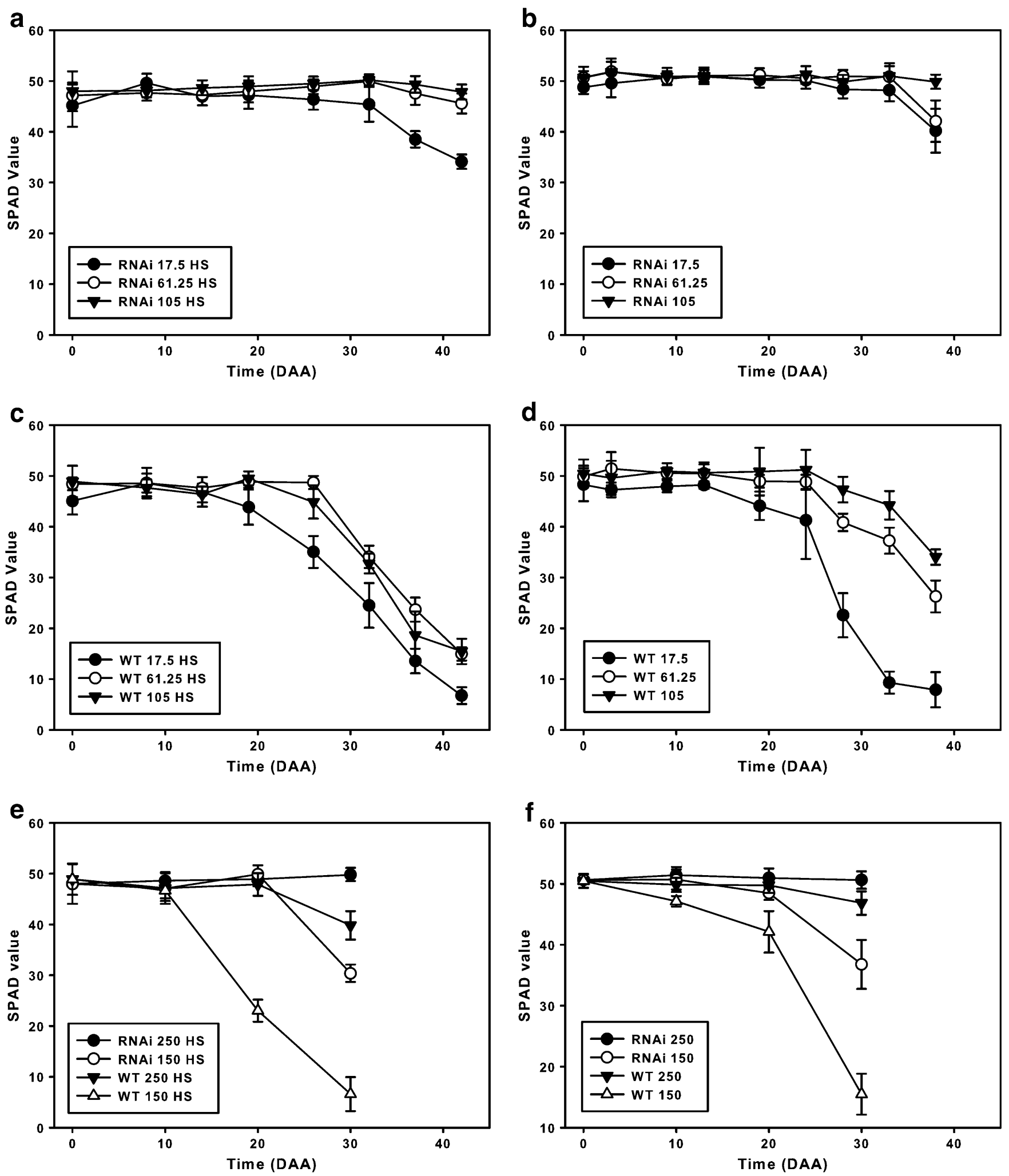

Figure 2. Flag leaf chlorophyll levels of TaNAM-RNAi and WT wheat plants determined by a Minolta SPAD meter. a-d: fertility study; $17.5,61.25$, and 105 refer to mg N supply per plant. a, TaNAM-RNAi plants grown in the heat stress environment; $\mathrm{b}, \mathrm{TaNAM}-\mathrm{RNAi}$ plants grown in the optimal temperature environment; $\mathrm{c}$, WT plants grown in the heat stress environment; $d, W T$ plants grown in the optimal temperature environment. e and f: moisture stress study; 150 and 250 refer to volumes of water supplied every $2 \mathrm{~d}$. e, TaNAM-RNAi and WT plants grown under heat stress; f, TaNAM-RNAi and WT plants grown under optimal temperatures. 
the TaNAM-RNAi and WT plants. In both environments, chlorophyll degradation was initiated earlier in WT plants than in TaNAM-RNAi plants. Senescence was earliest in plants of the low $\mathrm{N}$ treatments. Low N RNAi plants had $20 \%$ lower chlorophyll at $37 \mathrm{~d}$ under heat stress (Figure 2a) and $38 \mathrm{~d}$ under optimal temperatures (Figure 2b), while WT low $\mathrm{N}$ plants had $20 \%$ decreased chlorophyll at 24 $\mathrm{d}$ under the heat stress regime (Figure 2c) and $25 \mathrm{~d}$ under optimal temperatures (Figure 2d). TaNAMRNAi plants of intermediate and high $\mathrm{N}$ treatments had lost less than $20 \%$ of their chlorophyll concentration at the end of the experiment, while WT intermediate and high $\mathrm{N}$ lost $20 \%$ of chlorophyll at 30 $\mathrm{d}$ in the heat stress environment and $28 \mathrm{~d}$ in the optimal temperature environment. Thus, heat stress did not accelerate senescence of either WT or TaNAM-RNAi at low or intermediate $\mathrm{N}$ supply. High N WT plants lost $20 \%$ of chlorophyll at $30 \mathrm{~d}$ in the heat stress environment, while they senesced later under optimal temperatures, at $35 \mathrm{~d}$. The moisture stress studies were imposed at the high $\mathrm{N}$ rate only, and because of more rapid senescence, were terminated sooner than the fertility studies. Under heat stress at $20 \mathrm{~d}$ after anthesis, flag leaf chlorophyll in moisture stress treated WT plants had decreased by $52 \%$ (Figure 2e); under optimal temperatures, it had decreased by $14 \%$ (Figure 2f). In contrast, flag leaf chlorophyll was unchanged in TaNAM-RNAi plants under both heat and optimal environments. At $30 \mathrm{~d}$, WT plants had $86 \%$ lower chlorophyll in the heat stress environment with moisture stress and $68 \%$ lower under optimal temperatures with moisture stress. In comparison, chlorophyll in flag leaves of RNAi plants decreased $36 \%$ in the heat stress environment with moisture stress and $27 \%$ under moisture stress in the optimal temperature environment.

\section{WT vs RNAi in heat stress and optimal environments}

The fertility studies were conducted under wellwatered conditions; therefore effects of environment were not confounded with effects of moisture limitation in these studies. The responses of genotypes to environments are discussed first, averaged across $\mathrm{N}$ treatments, and specific interactions with fertility will be discussed below. Heat stress and optimal temperature environments produced substantial differences in seed yield in the fertility studies
(Table 1). Plants grown in the optimal temperature environments had vegetative mass approximately 3 times larger (data not shown), and 5 times the seed yield of plants grown in the heat stress environment, averaged over $\mathrm{N}$ treatments (Table 1). The heat stress environment diminished tiller number: these plants produced only primary tillers, whereas under the optimal temperature environment in Exp 2, the RNAi and WT plants averaged 3.0 and 2.7 tillers, respectively. The diminished tillering in the heat stress environment did not fully explain the effects of the high temperature environment on grain yield. Grain yields per spike of TaNAM-RNAi and WT plants in the heat stress environment were $58 \%$ and $56 \%$, respectively, of grain yield per spike in the optimal temperature environment, resulting from fewer seeds per spike under heat stress. The overall effect of genotype on seed yield was consistent and significant in the fertility studies (Table 1). In both experiments, TaNAM-RNAi plants produced significantly greater seed yield, with more seeds than WT, and with heavier seeds in heat stress environment (Table 1). The yield harvest index of WT, however, was greater than TaNAM-RNAi in both environments, because of greater vegetative biomass in the TaNAM-RNAi plants. Fertility treatments significantly affected kernel weight in both environments (Table 1). Under the heat stress environment, kernel weight was maximized by intermediate fertility (Figure 3); however, under optimal temperatures, kernel weight was lowest at intermediate fertility.

Seed protein concentration of TaNAM-RNAi was significantly lower than WT in both environments (Table 2, Figure 4). Despite increased seed yield of TaNAM-RNAi plants, WT plants had significantly greater total quantities of seed $\mathrm{N}$ (Table 2). Averaged across $\mathrm{N}$ treatments, $\mathrm{N}$ remobilization efficiencies were lower in TaNAM-RNAi than WT plants, at $19.4 \%$ v. $42.3 \%$, respectively, under heat stress, and $59.1 \%$ v. $74.9 \%$, respectively, under optimal temperatures (Table 2), although due to variability this difference was not statistically significant in the optimal temperature environment. Partitioning of $\mathrm{N}$ to seeds, measured as $\mathrm{N}$ harvest index, was greater in WT plants in both environments. Because treatments affected plant morphology and grain harvest index, the partitioning quotient (ratio of NHI/HI) was used to compare nitrogen use efficiency (NUE) among treatments. Partitioning quotients were normalized to the mean of 
Table 1. Effect of genotype, TaNAM-RNAi or Wild-type (WT), on vegetative biomass and yield components in fertility studies conducted under heat stress and optimal temperature environments. Means are presented as the mean \pm standard error

\begin{tabular}{|c|c|c|c|c|c|c|c|c|}
\hline Genotype & Tiller no. & $\begin{array}{l}\text { Plant dwt } \\
\text { per tiller }\end{array}$ & $\begin{array}{l}\text { Seed no. } \\
\left(\text { seeds plant }^{-1}\right)\end{array}$ & $\begin{array}{l}\text { Seeds } \\
\text { )per spike }\end{array}$ & $\begin{array}{l}\text { Kernel wt } \\
\left(\mathrm{mg} \mathrm{kernel}^{-1}\right)\end{array}$ & $\begin{array}{l}\text { Seed yield } \\
\left(\text { g plant }^{-1}\right)\end{array}$ & $\begin{array}{l}\text { Seed yield } \\
\left(\mathrm{g} \mathrm{spike}^{-1}\right)\end{array}$ & $\begin{array}{l}\text { Harvest } \\
\text { index }\end{array}$ \\
\hline \multicolumn{9}{|c|}{ Heat stress environment } \\
\hline WT & 1.0 & $0.97 \pm 0.04$ & $18.6 \pm 0.8$ & $18.6 \pm 0.8$ & $35.1 \pm 0.4$ & $0.66 \pm 0.03$ & $0.66 \pm 0.03$ & $0.400 \pm 0.007$ \\
\hline \multicolumn{9}{|l|}{ F-value } \\
\hline Geno $\times$ Fert & ns & ns & $5.3^{*}(2)$ & $5.3^{*}(2)$ & ns & $4.2^{*}(2)$ & $4.2^{*}(2)$ & ns \\
\hline \multicolumn{9}{|c|}{ Optimal temperature environment } \\
\hline TaNAM-RNAi & $3.01 \pm 0.12$ & $1.58 \pm 0.05$ & $107 \pm 5$ & $36.0 \pm 1.1$ & $35.8 \pm 0.5$ & $3.78 \pm 0.17$ & $1.30 \pm 0.04$ & $0.452 \pm 0.006$ \\
\hline WT & $2.74 \pm 0.13$ & $1.22 \pm 0.05$ & $88 \pm 5$ & $32.1 \pm 1.1$ & $35.0 \pm 0.5$ & $3.20 \pm 0.18$ & $1.16 \pm 0.04$ & $0.488 \pm 0.007$ \\
\hline Geno $\times$ Fert & ns & ns & ns & ns & ns & ns & ns & $4.6^{*}(2)$ \\
\hline
\end{tabular}

a. The F-value was determined by analysis of variance. Values in parentheses after significant effects of fertility treatment indicate the highest order of the response $(1=$ linear; 2 =quadratic $)$ to fertility treatment

* and ${ }^{* *}$ indicate significance at $p<0.05$ and 0.01 , respectively; ns $=$ non-significant

the study to facilitate discussion of relative effects of treatments on nutrient use efficiency (as per (Masclaux-Daubresse and Chardon 2011)). The normalized partitioning quotient (NPQ) for $\mathrm{N}$ of the WT was $>100$ in under both heat stress and optimal temperature environments, while the NPQ of TaNAMRNAi was $<100$ under both heat stress and optimal temperature environments (Table 2), indicating that WT plants had greater NUE than the TaNAM-RNAi line plants under both environments. Concentrations of minerals in vegetative tissues and contents for vegetative and seed tissues analyzed in the fertility studies are included in Online Resource 1. The mineral concentrations of seeds (Table 3 ) grown in the optimal temperature environment were similar to the concentration in seeds grown in the heat stress environment. The concentration of most minerals was greater in seed of WT plants than in seed of TaNAM-RNAi plants in both environments, with the exception of K, which was lower in WT. The TaNAM-RNAi genotype affected partitioning of minerals between reproductive and vegetative tissues. Similar to the N NPQ results, TaNAM-RNAi plants generally were less efficient in partitioning minerals into grain $(\mathrm{NPQ}<100)$, while WT plants generally had NPQs>100 (Figure 5). However, in both heat stress and optimal temperature environments, WT partitioned less $\mathrm{K}$ to grain in proportion to dry matter than the TaNAM-RNAi line.

\section{WT vs RNAi at differing $N$ rates}

WT seed yield and seed quantity had second-order responses to fertility when grown in the heat stress environment; however, seed yield and quantity of TaNAM-RNAi plants was not affected by fertility when grown under heat stress (Table 1, Figure 3). In the heat stress environment, fertility treatment did not affect seed protein concentration (Table 2, Figure 4). In contrast, in the optimal temperature environment, $\mathrm{N}$ concentration in seed increased linearly with increasing fertility. Seed protein concentration of the TaNAM-RNAi and WT genotypes responded similarly to fertility treatments in both environments, although the TaNAMRNAi line had consistently much lower GPC (approximately $28 \%$ lower) than WT.

$\mathrm{N}$ fertility treatment affected $\mathrm{N}$ harvest index (NHI) and NPQ similarly in WT and TaNAM-RNAi plants in both environments (Table 2). Effects of fertility treatments were small relative to effects of genotype in both environments. Therefore, despite 

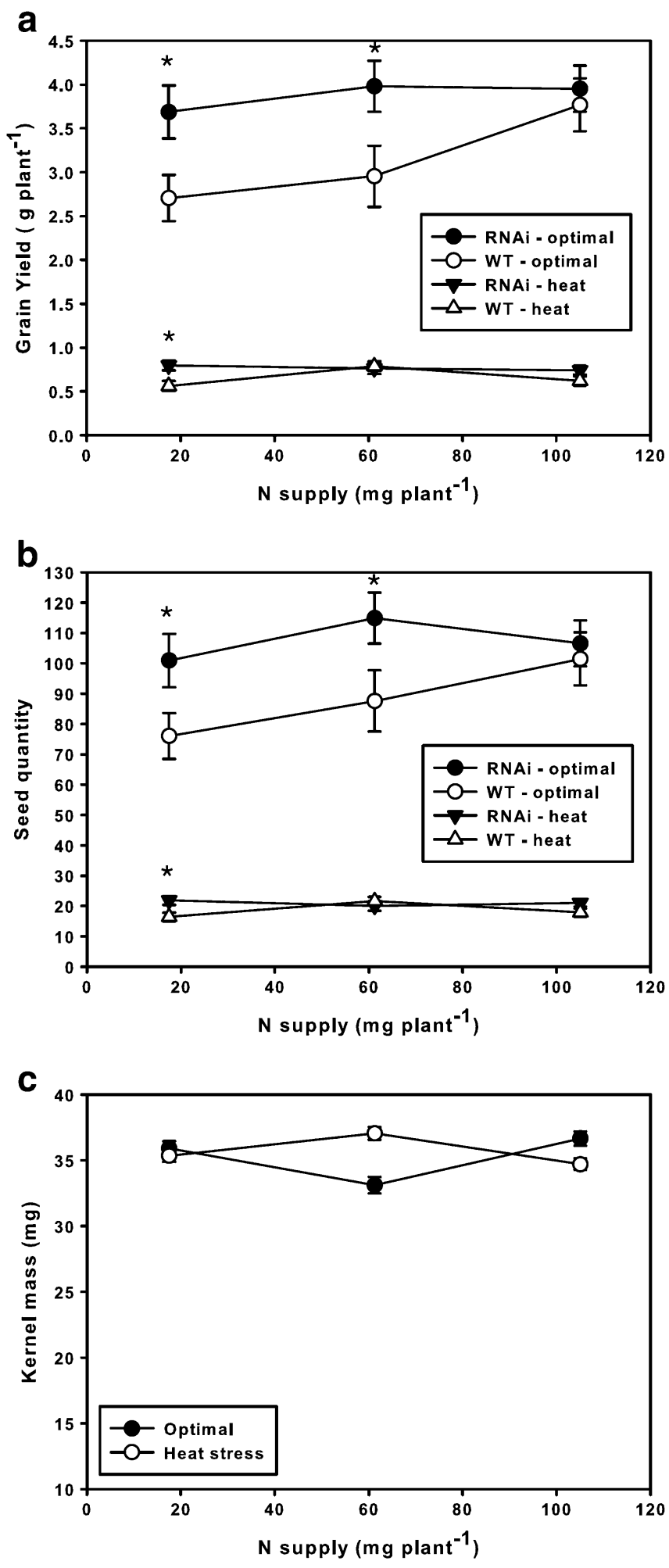

Figure 3. Grain yield and seed number and kernel mass of TaNAM-RNAi and WT wheat plants in the fertility study. a, grain yield; b, seed quantity per plant in the heat stress and optimal temperature environments; c, mass per kernel, averaged across genotypes. Asterisk indicates that F-value is significant between genotypes at $p<0.05$ varying responses to fertility treatment in the two environments, in both environments, TaNAM-RNAi plants partitioned less $\mathrm{N}$ to grain than $\mathrm{WT}$ plants. $\mathrm{Ta}$ NAM-RNAi plants consistently had lower net nitrogen remobilization efficiency than WT plants (Table 2). WT and TaNAM-RNAi plants had similar post-anthesis $\mathrm{N}$ accumulation (PANA) in each environment (Figure 5), which was affected by fertility treatment significantly in both environments. Similar to other rate responses in this experiment, PANA was at a maximum at the intermediate rate of $\mathrm{N}$ under heat stress. However, in optimal temperatures, PANA was relatively constant at the two lowest $\mathrm{N}$ rates (41 to $47 \mathrm{mg}$ plant ${ }^{-1}$ ), but was much greater $\left(84 \mathrm{mg}_{\text {plant }}{ }^{-1}\right)$ at the highest $\mathrm{N}$ rate. Again, despite the differences in effects of fertility treatments in the two environments, PANA of the two genotypes responded similarly to fertility treatment across environments.

Under the heat stress environment (Exp 1), fertility treatment interactions (across genotypes) were significant for partitioning of all minerals (except $\mathrm{Cu}$ ) to seed (Online Resource 2), with NPQ increasing (mineral utilization efficiency increasing) as $\mathrm{N}$ rate increased. As exceptions, partitioning of $\mathrm{Mn}, \mathrm{Mo}$, and $\mathrm{Cd}$ decreased as $\mathrm{N}$ rate increased. The two genotypes responded similarly, except for $\mathrm{S}$ and $\mathrm{Zn}$. Under the optimal temperature environment, partitioning of minerals to grain (across genotypes) increased with increasing $\mathrm{N}$ only for $\mathrm{Mn}$, while partitioning of $\mathrm{S}$ was negatively correlated with $\mathrm{N}$ rate. There were significant quadratic effects of fertility on partitioning of $\mathrm{K}$, $\mathrm{Fe}$, and $\mathrm{Cu}$. In the TaNAM-RNAi line, as $\mathrm{N}$ increased mineral partitioning of $\mathrm{Mg}, \mathrm{Ca}, \mathrm{Mn}, \mathrm{Fe}, \mathrm{Cu}, \mathrm{Zn}$, and $\mathrm{Cd}$ tended to remain constant or decrease, while in the WT mineral partitioning was lowest at low $\mathrm{N}$ and was highest at the intermediate $\mathrm{N}$ rate.

We observed decreased per tiller contents of $\mathrm{Cu}$, $\mathrm{Fe}, \mathrm{P}$, and $\mathrm{Zn}$ at maturity, indicating remobilization, in certain conditions. In the fertility study, in the heat stress environment both TaNAM-RNAi and WT plants remobilized $\mathrm{Cu}$ only under high $\mathrm{N}$ supply (Figure 7a), Fe accumulated in low N TaNAMRNAi plants and was remobilized in high and low $\mathrm{N}$ WT plants, and Zn was remobilized in high $\mathrm{N}$ WT plants. However, under optimal temperatures (Figs. 7b and d), both WT and RNAi plants remobilized $\mathrm{Fe}, \mathrm{P}$, and $\mathrm{Zn}$ in almost all conditions, however, the TaNAM-RNAi line plants did not remobilize $\mathrm{Cu}$, and WT plants did not remobilize $\mathrm{Cu}$ under water limitation. 


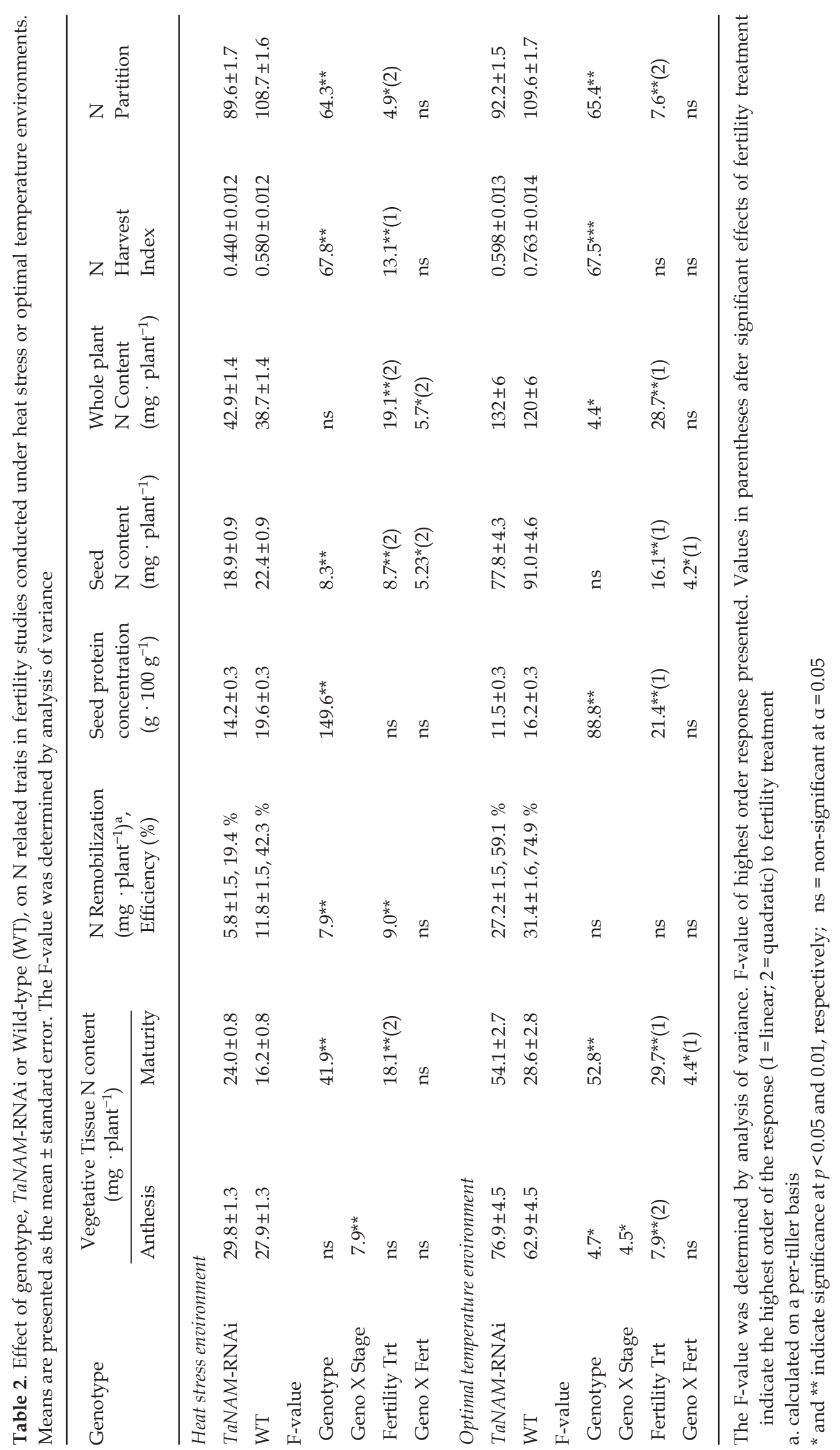



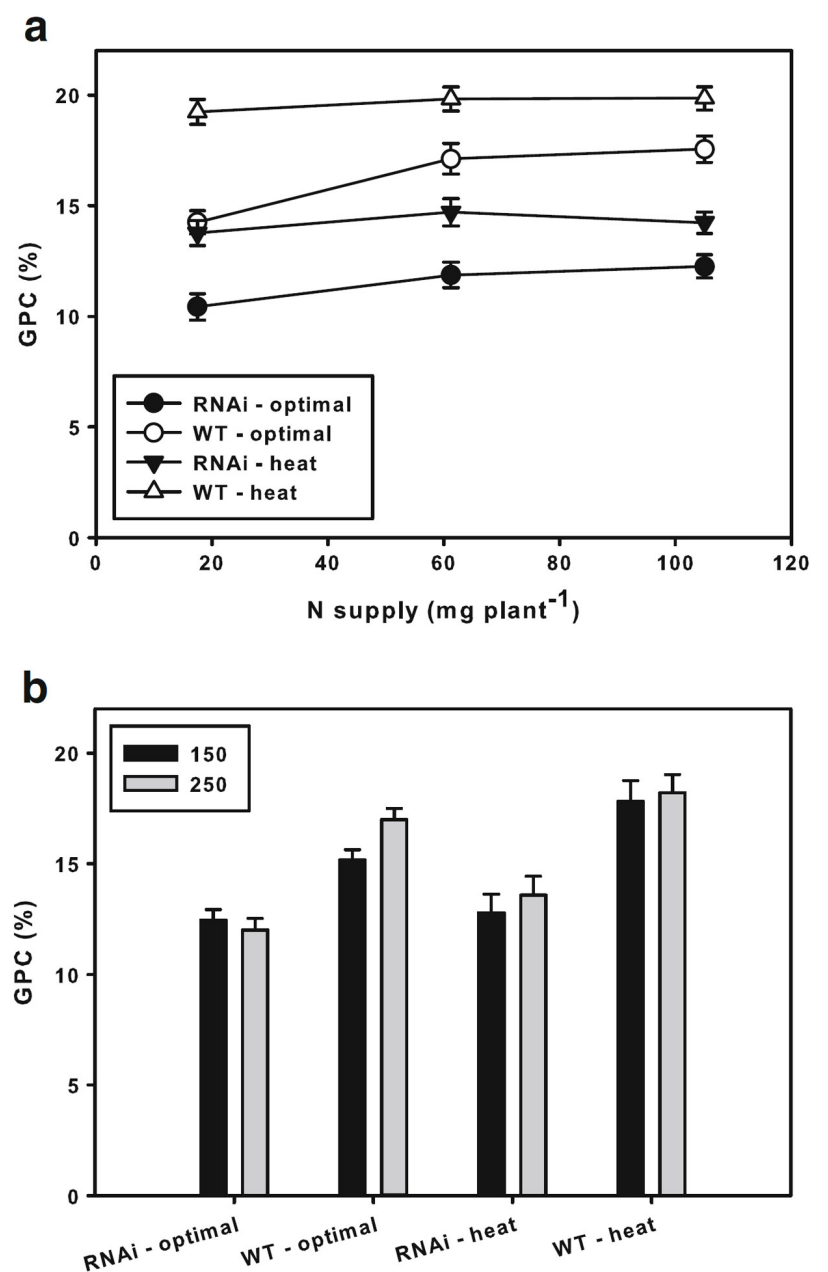

Figure 4. Grain protein concentration (GPC) of grain grown in heat stress and optimal temperature environments in fertility (a) and moisture stress (b) studies

\section{Moisture stress}

In general, TaNAM-RNAi and WT plants responded similarly to post-anthesis moisture stress. The RNAi line accumulated greater vegetative DW than WT, but grain yields were not different between the genotypes. Therefore yield harvest index was greater in WT plants than TaNAM-RNAi plants in the heat stress environment (Table 4). Across genotypes, moisture stress significantly reduced vegetative biomass in both temperature regimes. Total grain yield and seed number were decreased by moisture stress only under optimal temperatures, while seed size was reduced by moisture deficit only in the heat stress environment.

Total plant $\mathrm{N}$ content decreased with moisture deficit in both environments, and genotypes responded similarly to moisture deficit (Table 5). Under optimal temperatures, seed protein concentration of TaNAM-RNAi grain under moisture stress and well-watered treatments was $12.5 \%$ and $12.0 \%$, respectively, while seed protein concentration of WT grain under moisture stress and well-watered conditions was $15.2 \%$ and $17.0 \%$, respectively (Table 5, Figure 4). Across genotypes, moisture deficit reduced NHI and normalized partitioning of $\mathrm{N}$ to grain (NPQ) in the heat stress environment, but did not affect NPQ or NHI under optimal temperatures.

Mineral concentrations of seeds generally were decreased by moisture deficit in both environments (Online Resource 3). Seed mineral concentrations of the two genotypes generally responded similarly to water limitation. Similar to the fertility studies, WT plants utilized minerals more efficiently than TaNAM-RNAi plants: WT plants had mineral NPQ>100, while TaNAM-RNAi plants generally had NPQ $<100$ (Online Resource 4). In both heat stress and optimal temperature environments $\mathrm{K}$ was an exception, and had higher relative partitioning to grain in TaNAM-RNAi than in WT. In the heat stress environment, WT and RNAi lines responded differently, in terms of NPQ, to moisture stress for $\mathrm{Mg}, \mathrm{P}$, $\mathrm{S}, \mathrm{K}, \mathrm{Ca}, \mathrm{Fe}$, and $\mathrm{Cd}$, while under optimal temperatures genotypes responded differently only for $\mathrm{S}, \mathrm{K}$, and $\mathrm{Cu}$.

\section{Discussion}

\section{Senescence and yield under optimal and stress conditions}

Field-grown wheat in temperate climates commonly experiences stressful conditions during the grain filling period, including temperature stress, moisture stress, and nutrient deficiency. Climate change is expected to increase the frequency and severity of heat stress and drought events (Ahuja et al. 2010; Long and Ort 2010). Avoidance of senescence under stress (stay-green) has been associated with maintained yield in grain crops (Harris et al. 2007; Snape et al. 2007; Thomas and Howarth 2000; Zheng et al. 2009). Because the TaNAM-RNAi line exhibited delayed senescence in previous studies, we hypothesized that this line may also have delayed senescence under stress conditions, which would potentially result in improved yield under stress. Senescence of 
Table 3. Effect of genotype, TaNAM-RNAi or Wild-type, on mineral concentrations in seeds of plants grown in greenhouse fertility studies conducted under heat stress and optimal temperature environments. Data are means over fertility treatments. ANOVA was used to test significance of genotype effects

\begin{tabular}{|c|c|c|c|c|}
\hline & \multicolumn{4}{|c|}{ Concentration in Seed at Maturity } \\
\hline & \multicolumn{2}{|c|}{ Heat stress environment } & \multicolumn{2}{|c|}{ Optimal temperature environment } \\
\hline & TaNAM-RNAi & Wild-type & TaNAM-RNAi & Wild-type \\
\hline $\mathrm{P}$ & $3040 \pm 100$ & $3880 \pm 100 * *$ & $3791 \pm 107$ & $4017 \pm 115$ \\
\hline$S$ & $1520 \pm 40$ & $1830 \pm 40^{* *}$ & $2084 \pm 44$ & $2291 \pm 48^{* *}$ \\
\hline Mn & $42.0 \pm 1.5$ & $51.6 \pm 1.4^{* *}$ & $50.8 \pm 1.9$ & $54.8 \pm 2.0$ \\
\hline $\mathrm{Fe}$ & $32.5 \pm 1.7$ & $48.5 \pm 1.6^{* *}$ & $34.4 \pm 1.3$ & $43.7 \pm 1.4^{* *}$ \\
\hline $\mathrm{Cu}$ & $3.80 \pm 0.14$ & $4.84 \pm 0.14^{* *}$ & $3.75 \pm 0.33$ & $4.91 \pm 0.36^{*}$ \\
\hline $\mathrm{Zn}$ & $45.6 \pm 2.2$ & $56.2 \pm 2.1^{* *}$ & $34.9 \pm 1.5$ & $36.8 \pm 1.6$ \\
\hline Mo & $0.834 \pm 0.046$ & $1.264 \pm 0.045^{* *}$ & $0.825 \pm 0.035$ & $1.123 \pm 0.037^{* *}$ \\
\hline $\mathrm{Cd}$ & $0.148 \pm 0.008$ & $0.216 \pm 0008^{* *}$ & $0.201 \pm 0.013$ & $0.257 \pm 0.014^{* *}$ \\
\hline
\end{tabular}

* and ** indicate that F-value for genotype effect is significant at $p<0.05$ and 0.01 , respectively

TaNAM-RNAi plants was significantly delayed relative to WT plants in all optimal and stress conditions, including low $\mathrm{N}$, heat stress and water limitation (Figure 2), suggesting that triggering of stress induced senescence may rely at least partially on elements of the NAM gene regulatory network. Moisture deficit in the heat stress environment substantially accelerated senescence in WT plants, which had lost $>50 \%$ chlorophyll concentration when wellwatered WT plants were just beginning to senesce. TaNAM-RNAi plants also senesced earlier under the heat stress environment with moisture deficit compared to when well-watered, but the effect of moisture stress was modest relative to WT. However, the delayed senescence trait did not provide seed yield protection against post-anthesis moisture deficit (Tables 1 and 4). Under well-watered conditions, there was a yield advantage for the TaNAM-RNAi plants, as TaNAM-RNAi plants produced more and heavier seeds than the WT. A previous study also observed increased seed numbers in TaNAM-RNAi plants (Waters et al. 2009). The yield HI of WT, however, was greater than TaNAM-RNAi in well-watered plants under both heat stress and optimal temperature environments (Exp 1 and 2, Table 1), and under moisture stress in the heat stress environment (Exp 1, Table 4).

\section{How does stress affect $N$ utilization and GPC?}

Previous studies have reported higher wheat GPC under heat and/or moisture stress conditions (Correll et al. 1994; Ercoli et al. 2008, 2010; Gooding et al. 2003). In our experiments, the WT line
Figure 5. Normalized mineral partitioning quotients for TaNAMRNAi and WT wheat plants from heat stress (HS) and optimal temperature environments in the fertility study. *,** indicate that F-value is significant between genotypes at $p<0.05$ and 0.01 , respectively

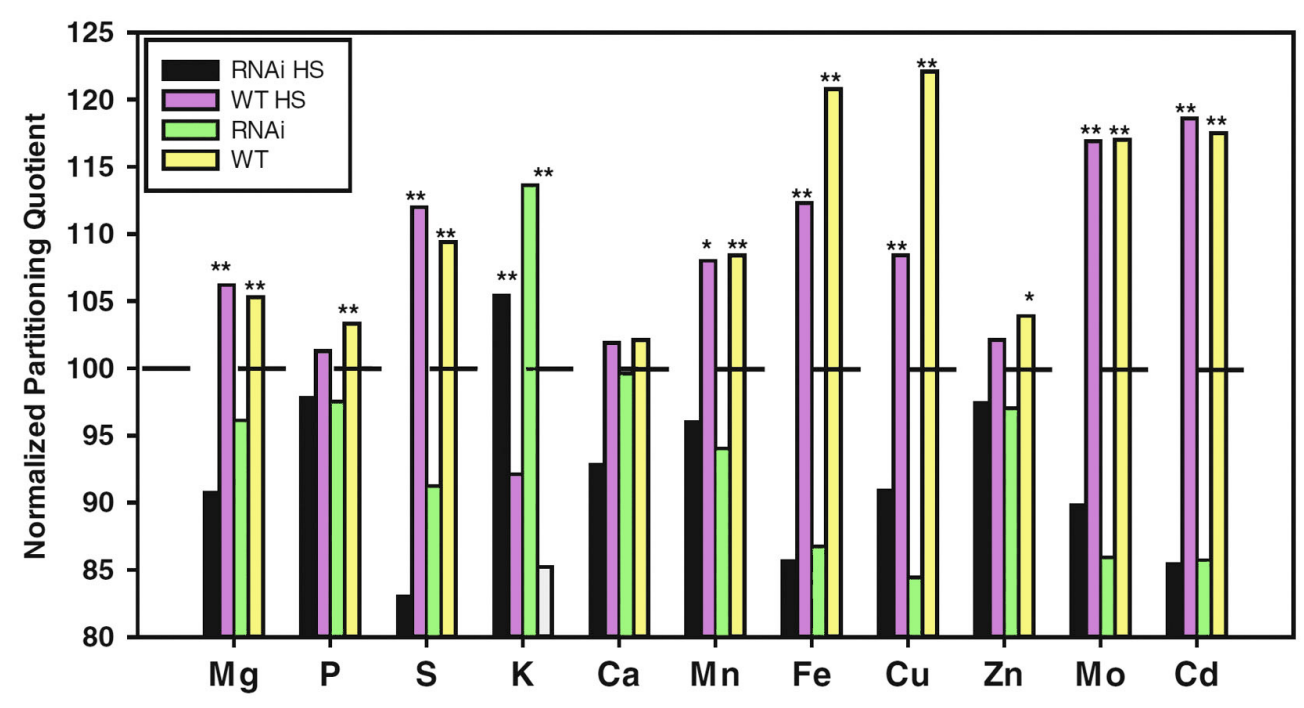




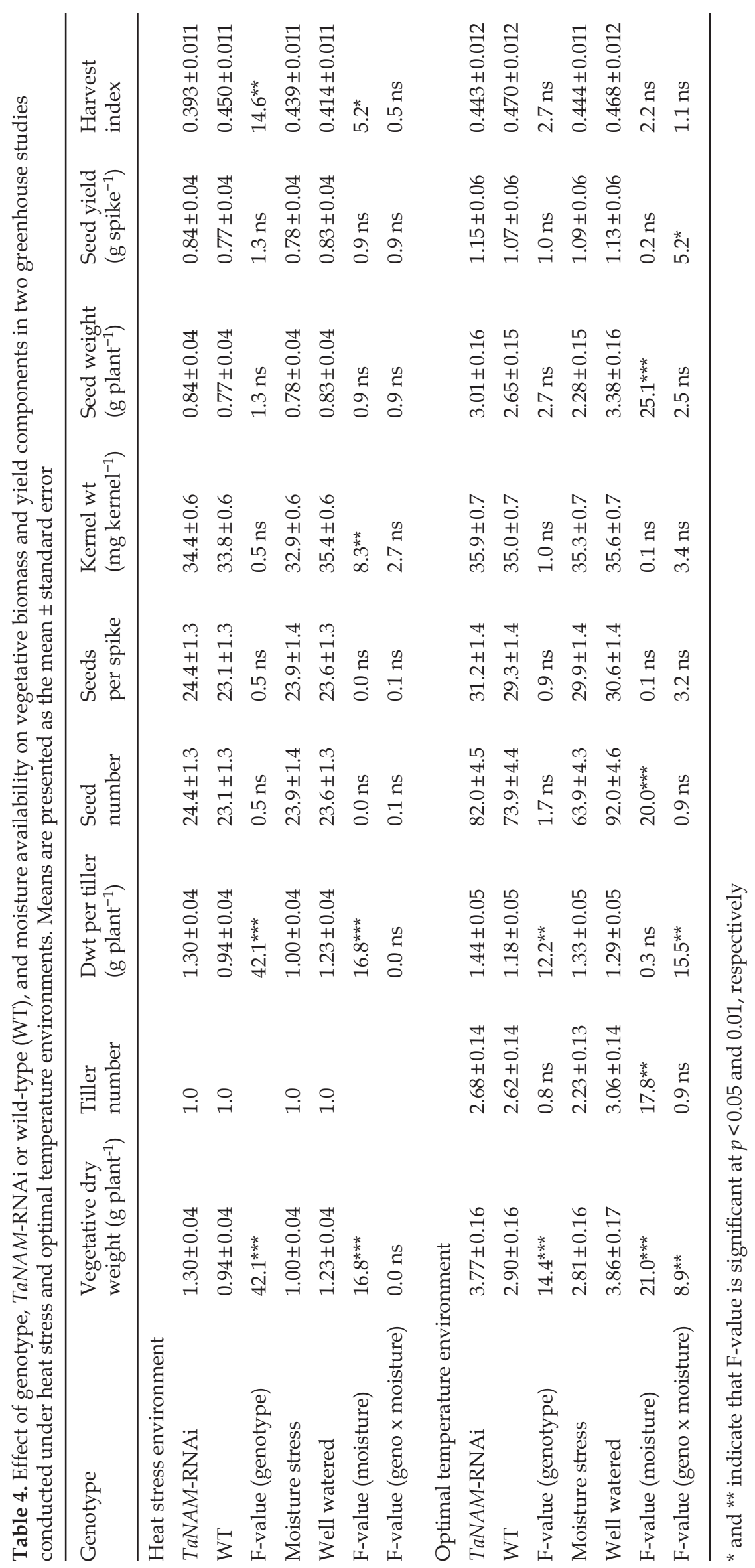


Table 5. Effect of genotype, TaNAM-RNAi or Wild-type (WT), and moisture availability on plant N related traits in two greenhouse studies conducted under heat stress (and optimal temperature environments. Means are presented as the mean \pm standard error

\begin{tabular}{|c|c|c|c|c|c|c|}
\hline Genotype & $\begin{array}{l}\text { N Remobilization } \\
\left(\mathrm{mg} \cdot \text { plant }^{-1}\right)^{\mathrm{a}}, \\
\text { Efficiency }(\%)\end{array}$ & $\begin{array}{l}\text { Seed protein } \\
\text { conc }(\%)\end{array}$ & $\begin{array}{l}\text { Seed N } \\
\text { content } \\
\left(\mathrm{mg} \mathrm{plant}^{-1}\right)\end{array}$ & $\begin{array}{l}\text { Whole plant } \\
\text { N content } \\
\left(\mathrm{mg} \mathrm{plant}^{-1}\right)\end{array}$ & $\begin{array}{l}\text { N Harvest } \\
\text { Index }\end{array}$ & N Partition \\
\hline \multicolumn{7}{|l|}{ Heat stress environment } \\
\hline TaNAM-RNAi & $4.7 \pm 1.9,15.9 \%$ & $13.2 \pm 0.6$ & $19.4 \pm 1.5$ & $44.3 \pm 1.9$ & $0.440 \pm 0.018$ & $85.9 \pm 2.3$ \\
\hline WT & $20.7 \pm 1.9,63.3 \%$ & $18.0 \pm 0.6$ & $24.2 \pm 1.5$ & $36.2 \pm 2.0$ & $0.673 \pm 0.019$ & $115.7 \pm 2.4$ \\
\hline F-value (genotype) & $36.7^{* *}$ & $31.3^{* *}$ & $5.2^{*}$ & $8.8^{* *}$ & $81.7^{* * *}$ & $82.4^{* *}$ \\
\hline F-value (moisture) & $10.4^{* *}$ & $0.5 \mathrm{~ns}$ & $1.7 \mathrm{~ns}$ & $16.6^{* * *}$ & $12.6^{* *}$ & $6.6^{*}$ \\
\hline F-value (geno $x$ moisture) & $0.4 \mathrm{~ns}$ & $0.1 \mathrm{~ns}$ & $0.6 \mathrm{~ns}$ & $0.0 \mathrm{~ns}$ & $0.1 \mathrm{~ns}$ & $0.5 \mathrm{~ns}$ \\
\hline \multicolumn{7}{|c|}{ Optimal temperature environment } \\
\hline TaNAM-RNAi & $29.6 \pm 1.6,64.2 \%$ & $12.2 \pm 0.4$ & $64.4 \pm 4.1$ & $108 \pm 5.2$ & $0.598 \pm 0.019$ & $91.4 \pm 2.8$ \\
\hline F-value (moisture) & $0.1 \mathrm{~ns}$ & $2.0 \mathrm{~ns}$ & $25.6^{* *}$ & $36.8^{* * *}$ & $0.2 \mathrm{~ns}$ & $0.2 \mathrm{~ns}$ \\
\hline F-value (geno $x$ moisture) & $2.5 \mathrm{~ns}$ & $5.3^{*}$ & $0.0 \mathrm{~ns}$ & $1.6 \mathrm{~ns}$ & $2.9 \mathrm{~ns}$ & $2.9 \mathrm{~ns}$ \\
\hline
\end{tabular}

a. calculated on a per-tiller basis

${ }^{*}$ and ${ }^{* *}$ indicate that F-value is significant at $p<0.05$ and 0.01 , respectively

consistently had higher GPC than the TaNAM-RNAi line (Tables 2 and 5, Figure 4), consistent with previous studies (Uauy et al. 2006b; Waters et al. 2009). The exceptionally high seed protein concentrations (>19 \%) of WT seeds from the heat stress environment (Table 2, Figure 4) suggests that the second-order effects observed may be a consequence of excess fertility application at the limited yield potential of the plants. The lower GPC in the TaNAM-RNAi line was not due to decreased pre-anthesis accumulation of $\mathrm{N}$ (Tables 2 and 5), which was greater in the TaNAM-RNAi line or equivalent between the two lines. For N, heat stress has been shown to increase (Corbellini et al. 1997) or reduce remobilization (Ercoli et al. 2010), while drought stress reduced remobilization (Ercoli et al. 2008). Here, we observed that plants grown in the temperature stress environment had reduced $\mathrm{N}$ remobilization efficiency in both fertility and moisture stress studies. Part of the decrease in GPC in TaNAM-RNAi grain relative to WT was attributed to decreased remobilization in prior work (Waters et al. 2009), and our results here are consistent with this hypothesis (Tables 2 and 5). While PANA was equivalent between $\mathrm{WT}$ and $\mathrm{Ta}$ NAM-RNAi lines (Figure 6), NHI and NPQ were diminished in the TaNAM-RNAi line, indicating that the TaNAM-RNAi line less effectively remobilized vegetative $\mathrm{N}$ and translocated new $\mathrm{N}$ from vegetative tissues to grain. Under the high temperature environment, plants that experienced moisture stress had greater NHI and NPQ than wellwatered plants, but this relationship did not hold

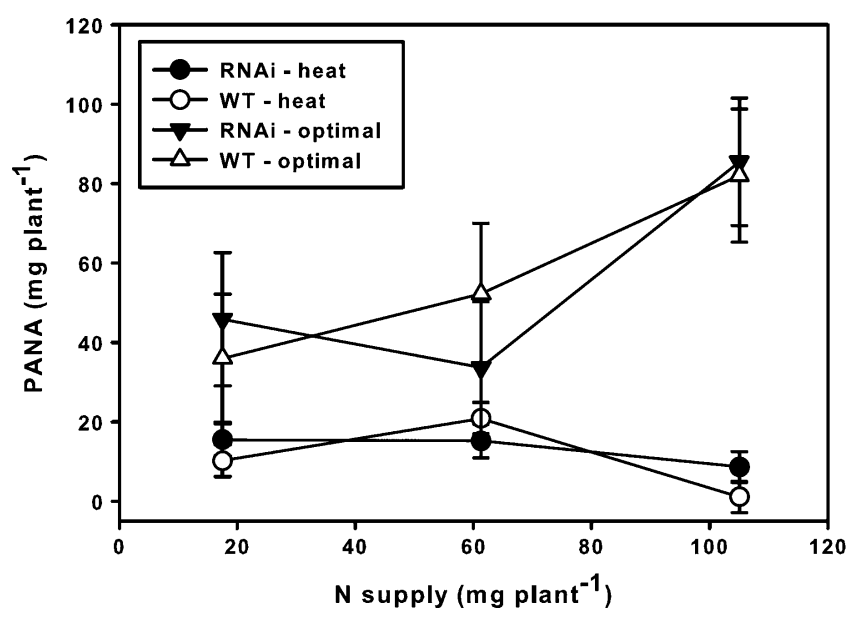

Figure 6. Post-anthesis $\mathrm{N}$ accumulation (PANA) in above-ground tissues of TaNAM-RNAi and WT wheat plants from heat stress and optimal temperature environments in the fertility study. There were no significant differences between genotypes 

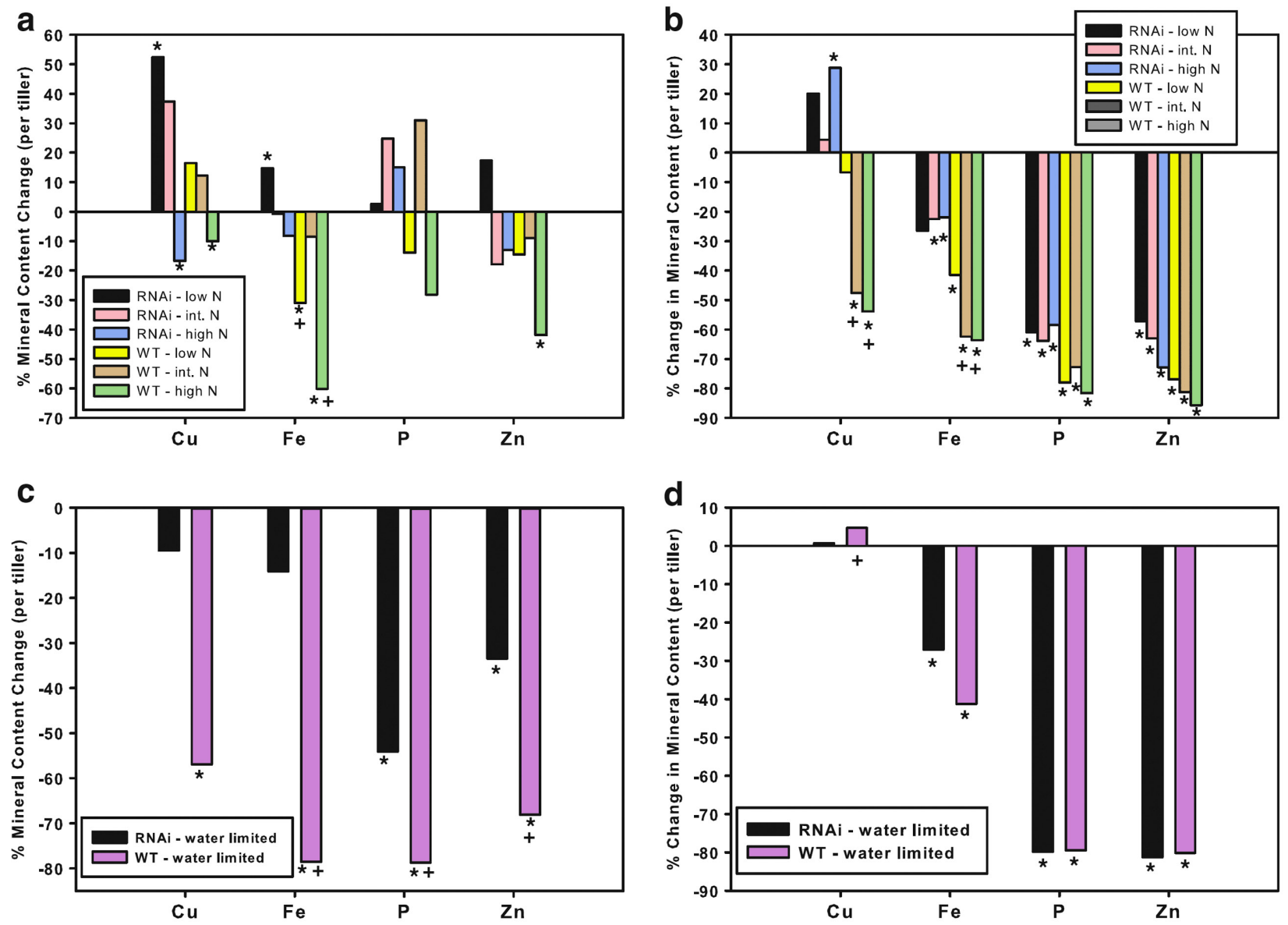

Figure 7. Remobilization of $\mathrm{Cu}, \mathrm{Fe}, \mathrm{P}$ and $\mathrm{Zn}$ from above-ground tissues of TaNAM-RNAi and WT wheat plants. a and b, fertility study; c and d, irrigation study. a and c, plants grown under heat stress conditions; b and d, plants grown under optimal temperatures. Negative values indicate net remobilization from vegetative tissues between anthesis and maturity. Asterisk indicates that F-value for mineral content change is significant, positive indicates that F-value for mineral content change is significant between genotypes at $p<0.05$

for plants in the optimal temperature environment (Table 5). At this point, it is not clear which specific gene products are needed to carry out partitioning, but it is clear that they are associated with senescence. Accompanying the delayed senescence in the TaNAM-RNAi line is differential regulation of several hundred genes (Cantu et al. 2011), which are not properly regulated in the TaNAM-RNAi line; it is likely that one or more of these genes are responsible for $\mathrm{N}$ partitioning to grain.

\section{How does stress affect mineral partitioning?}

Remobilization patterns of $\mathrm{Cu}, \mathrm{Fe}$, and $\mathrm{Zn}$ were altered in the heat stress environment (Figure 7). Optimal temperatures produced more consistency between $\mathrm{N}$ treatments. WT plants remobilized more $\mathrm{Cu}$ and Fe than the TaNAM-RNAi line in fertility studies under optimal temperatures, but $\mathrm{P}$ and $\mathrm{Zn}$ remobilization was similar. The effects of moisture stress on mineral concentrations of wheat grain are not well defined. Water limitation significantly affected grain ash concentration, with less ash at more severe water stress, and $\mathrm{Mg}$ concentration also was affected by drought, but not in a linear fashion (Zhu et al. 2008). In a study of 22 accessions of T. dicoccoides, well-watered or water limited conditions produced differences in grain Fe and Zn, but some accessions had greater concentrations under water limitation while others had the opposite response to water limitation (Peleg et al. 2008). Collections of $T$. spelta and $T$. dicoccoides grown under different environments revealed that environmental effects were the greatest factor in grain mineral concentrations (Gomez-Becerra et al. 2010a, b). Here, moisture stress in the heat stress environment revealed differences in remobilization of not only Fe, but also $\mathrm{P}$ and $\mathrm{Zn}$ between genotypes (Figure 7). Similarly, 
in the fertility study, remobilization of minerals affected the RNAi line greater than the WT in the heat stress environment. Thus, it appears likely that the lower remobilization capacity of the RNAi line is magnified by heat stress during the grain fill period. The greater remobilization in the WT certainly would have contributed to differences in partitioning between vegetative tissues and grain. Similar to $\mathrm{N}$, partitioning quotients for most minerals were lower in the RNAi line than in wild-type (Online Resource 4), suggesting that similar processes are used to partition $\mathrm{N}$ and minerals to grain during grain fill, and that knocking down NAM genes by RNAi influences these processes. Although we cannot directly compare the samples from the two environments, normalized PQ appeared to be largely unchanged between the heat stress environment and optimal temperature environment (Figure 5). This is consistent with a previous study that showed decreased translocation of newly taken-up radiolabeled $\mathrm{Zn}$ to grain in the TaNAM-RNAi line (Waters et al. 2009). A notable exception to this relationship was partitioning of $\mathrm{K}$ to grain, which was significantly greater in the TaNAM-RNAi line than in the WT (Online Resource 4, Figure 5). Across genotypes, moisture stress altered NPQ of several minerals under both optimal and heat stress temperature environments, but there were few consistent patterns between the two environments (online Resource 4). Nutrient harvest indices of TaNAM-RNAi and WT plants generally responded similarly to heat and moisture stress. The heat stress environment tended to decrease mineral PQ in the fertility study (Online Resource 2, Figure 5).

TaNAM-RNAi plants were larger overall, but had smaller quantities of nutrients partitioned to the grain, with similar or higher grain yield. The end result of this is a more dilute grain mineral density, as reflected in grain mineral concentrations (Table 3, Online Resource 3). In the fertility study, in the heat stress environment all minerals except Ca were significantly different between genotypes, with all of these being lower in the TaNAM-RNAi line except for $\mathrm{K}$, which was higher here and was higher in $\mathrm{Ta}$ NAM-RNAi grain in all other conditions as well (Online Resource 3). Under the optimal temperature regime in both the fertility and moisture stress studies, most mineral concentrations were greater in WT grain. These results are mostly consistent with results of previous evaluations of TaNAM-RNAi wheat (Uauy et al. 2006b; Waters et al. 2009) and extend the observations to stress conditions. However, in the previous studies, $\mathrm{Zn}$ concentration in $\mathrm{Ta}$ NAM-RNAi seed was lower than in WT seed, while here the concentration of $\mathrm{Zn}$ in seed of TaNAMRNAi plants was significantly lower only in the heat stress environment. When genotypes expressing the non-functional Gpc-B1 allele were compared with genotypes expressing the functional allele (Distelfeld et al. 2007), only the concentrations of $\mathrm{Fe}, \mathrm{Mg}$, and $\mathrm{Zn}$ were significantly different. The remobilization of $\mathrm{Zn}$ from vegetative tissues was previously shown to be lower in the RNAi line (Waters et al. 2009), whereas here no differences were observed. The soil-sand mix employed in this study did not receive additional Zn fertilization, and soil Zn concentration may have been too low to allow expression of differences previously observed.

Several studies have shown that increasing $\mathrm{N}$ supply positively affected $\mathrm{Fe}$ and/or $\mathrm{Zn}$ uptake and grain Fe and/or Zn concentrations (Aciksoz et al. 2011; Cakmak et al. 2010; Erenoglu et al. 2010; Gooding et al. 2012; Kutman et al. 2010, 2011a, 2012; b; Shi et al. 2010). In our fertility study, grain Fe was consistently higher in WT than in RNAi, but Zn was higher only under the heat stress environment (Table 3), and we did not observe increasing grain $\mathrm{Fe}$ and $\mathrm{Zn}$ with increasing $\mathrm{N}$ supply. Our results did show, however, that across genotypes, increasing $\mathrm{N}$ from the lowest rate resulted in improved nutrient use efficiency (NPQ) for both Fe and $\mathrm{Zn}$ in the heat stress fertility study, and increased nutrient use efficiency of Fe under optimal temperatures. The TaNAM-RNAi and WT genotypes responded differently to $\mathrm{N}$ supply for $\mathrm{Zn} P Q$ in both heat stress and optimal temperature environment, and for $\mathrm{Fe}$ PQ under optimal temperatures (Online Resource 2). However, in regard to grain mineral concentrations, in general, both genotypes responded similarly to moisture stress, and relative mineral concentrations between the genotypes were maintained in both optimal temperature and heat stress environments (Online resource 3). Thus, the delayed senescence of the RNAi line did not provide an advantage in terms of grain mineral concentrations.

\section{Conclusions and future directions}

A previous study showed that NAM genes were upregulated rapidly after anthesis in flag leaves. 
Here we show that the primary site of expression, at least in above-ground tissues, is the flag leaf, with some expression in senescing lower leaves (Figure 1). An unanswered question is how expression in flag leaf also controls senescence of peduncle and spike, which remained green in TaNAM-RNAi plants in previous studies and also this one. Nutritional quality, in terms of mineral and protein concentration, was decreased in the TaNAM-RNAi grain here and in the prior studies. Part of this decrease results from reduced net remobilization of minerals and part results from lower partitioning of minerals taken up during grain fill and directed to the grain as it is filling. Dry matter partitioning to grain was affected less than $\mathrm{N}$ and mineral partitioning to grain. Thus, another unanswered question is how decreased expression of NAM genes affects the translocation of $\mathrm{N}$ and minerals to grain. The pathways of $\mathrm{N}$ and minerals to grain are not fully defined (Waters and Sankaran 2011), and specific sites of phloem loading for transport to the grain are not known, although glumes, stem, roots, and leaves are all sources (Simpson et al. 1983). It is possible that $\mathrm{N}$ and minerals first move into the flag leaf to be directed into translocation pathways to the grain, which would make it easier to explain the relationship between the site of NAM expression and the effects of NAM knockdown. Since the NAM genes are transcription factors that potentially regulate a large number of direct target and downstream genes, in the future it may be possible to separate the effects on senescence onset from those on partitioning and grain nutritional quality. Transcriptome analysis identified 691 differentially regulated genes during senescence between the WT and TaNAMRNAi (Cantu et al. 2011). It is unlikely that the NAM proteins directly regulate all of these genes, and some of them are probably part of secondary networks. Thus, increased knowledge of direct NAM targets and their downstream networks could enable targeting of specific components that may permit selection for the beneficial effects of delayed senescence while avoiding the detrimental effects on nutritional quality.

Acknowledgments - The authors thank Shirley Sato and Tom Clemente (University of Nebraska, Lincoln, USA) for providing wheat plants for gene expression, Jorge Dubcovsky (University of California, Davis, USA) for providing TaNAM-RNAi and WT seeds, Stephen Baenziger (University of Nebraska, Lincoln, USA) for critical reading of the manuscript, and
Laura Armbrust, Grace Troupe, Sam McInturf, and Brad Edeal for technical assistance with sample processing. This research was funded in part by a grant to BMW from the UNL Agricultural Research Division, and the USDA-NIFA Triticeae-CAP grant (2011-68002-30029).

\section{References}

Aciksoz S, Yazici A, Ozturk L, Cakmak I (2011) Biofortification of wheat with iron through soil and foliar application of nitrogen and iron fertilizers. Plant Soil 349:215-225

Ahuja I, de Vos RCH, Bones AM, Hall RD (2010) Plant molecular stress responses face climate change. Trends Plant Sci 15:664-674

Asplund L, Hagenblad J, Leino MW (2010) Re-evaluating the history of the wheat domestication gene NAM-B1 using historical plant material. J Archaeol Sci 37:2303-2307

Barneix AJ (2007) Physiology and biochemistry of source-regulated protein accumulation in the wheat grain. J Plant Physiol 164:581-590

Black RE, Allen LH, Bhutta ZA, Caulfield LE, de Onis M, Ezzati M, Mathers C, Rivera J (2008) Maternal and child undernutrition: global and regional exposures and health consequences. Lancet 371:243-260

Bogard M, Allard V, Brancourt-Hulmel M, Heumez E, Machet J-M, Jeuffroy M-Hln, Gate P, Martre P, Le Gouis J (2010) Deviation from the grain protein concentration-grain yield negative relationship is highly correlated to post-anthesis $\mathrm{N}$ uptake in winter wheat. J Exp Bot 61:4303-4312

Bogard M, Jourdan M, Allard V, Martre P, Perretant MR, Ravel C, Heumez E, Orford S, Snape J, Griffiths S, Gaju O, Foulkes J, Le Gouis J (2011) Anthesis date mainly explained correlations between post-anthesis leaf senescence, grain yield, and grain protein concentration in a winter wheat population segregating for flowering time QTLs. J Exp Bot 62:3621-3636

Brevis JC, Morris CF, Manthey F, Dubcovsky J (2010) Effect of the grain protein content locus Gpc-B1 on bread and pasta quality. J Cereal Sci 51:357-365

Buchanan-Wollaston V, Page T, Harrison E, Breeze E, Lim PO, NAM HG, Lin JF, Wu SH, Swidzinski J, Ishizaki K, Leaver CJ (2005) Comparative transcriptome analysis reveals significant differences in gene expression and signalling pathways between developmental and dark/starvation-induced senescence in Arabidopsis. Plant J 42:567-585

Cakmak I, Kalayci M, Kaya Y, Torun AA, Aydin N, Wang Y, Arisoy Z, Erdem H, Yazici A, Gokmen O, Ozturk L, Horst WJ (2010) Biofortification and localization of zinc in wheat grain. J Agric Food Chem 58:9092-9102

Cakmak I, Torun A, Millet E, Feldman M, Fahima T, Korol A, Nevo E, Braun HJ, Ozkan H (2004) Triticum dicoccoides: An important genetic resource for increasing zinc and iron concentration in modern cultivated wheat. Soil Sci Plant Nutr 50:1047-1054

Cantu D, Pearce SP, Distelfeld A, Christiansen MW, Uauy C, Akhunov E, Fahima T, Dubcovsky J (2011) Effect of the 
down-regulation of the high Grain Protein Content (GPC) genes on the wheat transcriptome during monocarpic senescence. BMC Genomics 12:17

Corbellini M, Canevar MG, Mazza L, Ciaffi M, Lafiandra D, Borghi B (1997) Effect of the duration and intensity of heat shock during grain filling on dry matter and protein accumulation, technological quality and protein composition in bread and durum wheat. Funct Plant Biol 24:245-260

Correll R, Butler J, Spouncer L, Wrigley C (1994) The relationship between grain-protein content of wheat and barley and temperatures during grain filling. Funct Plant Biol 21:869-873

de Benoist B, McLean E, Egli I, Cogswell M (2008) Worldwide prevalence of anaemia 1993-2005. WHO Global Database on Anaemia

Distelfeld A, Cakmak I, Peleg Z, Ozturk L, Yazici AM, Budak H, Saranga Y, Fahima T (2007) Multiple QTL-effects of wheat $G p c-B 1$ locus on grain protein and micronutrient concentrations. Physiol Plant 129:635-643

Drossopoulos B, Kouchaji GG, Bouranis DL (1996) Seasonal dynamics of mineral nutrients and carbohydrates by walnut tree leaves. J Plant Nutr 19:493-516

Ercoli L, Arduini I, Mariotti M, Masoni A (2010) Post-anthesis dry matter and nitrogen dynamics in durum wheat as affected by nitrogen and temperature during grain filling. Cereal Res Commun 38:294-303

Ercoli L, Lulli L, Mariotti M, Masoni A, Arduini I (2008) Postanthesis dry matter and nitrogen dynamics in durum wheat as affected by nitrogen supply and soil water availability. Eur J Agron 28:138-147

Erenoglu EB, Kutman UB, Ceylan Y, Yildiz B, Cakmak I (2010) Improved nitrogen nutrition enhances root uptake, rootto-shoot translocation and remobilization of zinc $\left({ }^{65} \mathrm{Zn}\right)$ in wheat. New Phytol. doi:10.1111/j.1469-8137.2010.03488.x

Gepstein S, Sabehi G, Carp MJ, Hajouj T, Nesher MFO, Yariv I, Dor C, Bassani M (2003) Large-scale identification of leaf senescence-associated genes. Plant J 36:629-642

Gomez-Becerra HF, Erdem H, Yazici A, Tutus Y, Torun B, Ozturk L, Cakmak I (2010a) Grain concentrations of protein and mineral nutrients in a large collection of spelt wheat grown under different environments. J Cereal Sci 52:342-349

Gomez-Becerra HF, Yazici A, Ozturk L, Budak H, Peleg Z, Morgounov A, Fahima T, Saranga Y, Cakmak I (2010b) Genetic variation and environmental stability of grain mineral nutrient concentrations in Triticum dicoccoides under five environments. Euphytica 171:39-52

Gooding M, Ellis R, Shewry P, Schofield J (2003) Effects of restricted water availability and increased temperature on the grain filling, drying and quality of winter wheat. J Cereal Sci 37:295-309

Gooding M, Fan M, McGrath S, Shewry P, Zhao F-J (2012) Contrasting effects of dwarfing alleles and nitrogen availability on mineral concentrations in wheat grain. Plant Soil 360:93-107

Górny AG, Banaszak Z, Lugowska B, Ratajczak D (2011) Inheritance of the efficiency of nitrogen uptake and utilization in winter wheat (Triticum aestivum L.) under diverse nutrition levels. Euphytica 177:191-206

Gregersen PL, Holm PB, Krupinska K (2008) Leaf senescence and nutrient remobilisation in barley and wheat. Plant Biol 10:37-49

Harris K, Subudhi PK, Borrell A, Jordan D, Rosenow D, Nguyen H, Klein P, Klein R, Mullet J (2007) Sorghum staygreen QTL individually reduce post-flowering drought-induced leaf senescence. J Exp Bot 58:327-338

Hocking PJ (1994) Dry-matter production, mineral nutrient concentrations, and nutrient distribution and redistribution in irrigated spring wheat. J Plant Nutr 17:1289-1308

Hocking PJ, Pate JS (1977) Mobilization of minerals to developing seeds of legumes. Ann Bot 41:1259-1278

Hopkins M, Taylor C, Liu ZD, Ma FS, McNamara L, Wang TW, Thompson JE (2007) Regulation and execution of molecular disassembly and catabolism during senescence. New Phytol 175:201-214

Kade M, Barneix AJ, Olmos S, Dubcovsky J (2005) Nitrogen uptake and remobilization in tetraploid 'Langdon' durum wheat and a recombinant substitution line with the high grain protein gene Gpc-B1. Plant Breed 124:343-349

Karami M, Afyuni M, Khoshgoftarmanesh AH, Papritz A, Schulin R (2009) Grain zinc, iron, and copper concentrations of wheat grown in central Iran and their relationships with soil and climate variables. J Agric Food Chem 57:10876-10882

Kichey T, Hirel B, Heumez E, Dubois F, Le Gouis J (2007) In winter wheat (Triticum aestivum L.), post-anthesis nitrogen uptake and remobilisation to the grain correlates with agronomic traits and nitrogen physiological markers. Field Crops Res 102:22-32

Kutman U, Kutman B, Ceylan Y, Ova E, Cakmak I (2012) Contributions of root uptake and remobilization to grain zinc accumulation in wheat depending on post-anthesis zinc availability and nitrogen nutrition. Plant Soil. 361:177-187

Kutman UB, Yildiz B, Cakmak I (2011a) Effect of nitrogen on uptake, remobilization and partitioning of zinc and iron throughout the development of durum wheat. Plant Soil 342:149-164

Kutman UB, Yildiz B, Cakmak I (2011b) Improved nitrogen status enhances zinc and iron concentrations both in the whole grain and the endosperm fraction of wheat. J Cereal Sci 53:118-125

Kutman UB, Yildiz B, Ozturk L, Cakmak I (2010) Biofortification of durum wheat with zinc through soil and foliar applications of nitrogen. Cereal Chem 87:1-9

Lim PO, Kim HJ, NAM HG (2007) Leaf senescence. Annu Rev Plant Biol 58:115-136

Long SP, Ort DR (2010) More than taking the heat: crops and global change. Curr Opin Plant Biol 13:240-247

Mao X, Zhang H, Qian X, Li A, Zhao G, Jing R (2012) TaNAC2, a NAC-type wheat transcription factor conferring enhanced multiple abiotic stress tolerances in Arabidopsis. J Exp Bot 63:2933-2946 
Masclaux-Daubresse C, Daniel-Vedele F, Dechorgnat J, Chardon F, Gaufichon L, Suzuki A (2010) Nitrogen uptake, assimilation and remobilization in plants: challenges for sustainable and productive agriculture. Ann Bot 105:1141-1157

Masclaux-Daubresse C, Reisdorf-Cren M, Orsel M (2008) Leaf nitrogen remobilisation for plant development and grain filling. Plant Biol 10:23-36

Masclaux-Daubresse CL, Chardon F (2011) Exploring nitrogen remobilization for seed filling using natural variation in Arabidopsis thaliana. J Exp Bot 62:2131-2142

Masoni A, Ercoli L, Mariotti M, Arduini I (2007) Post-anthesis accumulation and remobilization of dry matter, nitrogen and phosphorus in durum wheat as affected by soil type. Eur J Agron 26:179-186

Miller RO, Jacobsen JS, Skogley EO (1994) Aerial accumulation and partitioning of nutrients by hard red spring wheat. Commun Soil Sci Plant Anal 25:1891-1911

Morgounov A, Gomez-Becerra HF, Abugalieva A, Dzhunusova M, Yessimbekova M,

Muminjanov H, Zelenskiy Y, Ozturk L, Cakmak I (2007) Iron and zinc grain density in common wheat grown in Central Asia. Euphytica 155:193-203

Murphy KM, Hoagland LA, Yan L, Colley M, Jones SS (2011) Genotype $x$ Environment interactions for mineral concentration in grain of organically grown spring wheat. Agron J 103:1734-1741

Nakashima K, Takasaki H, Mizoi J, Shinozaki K, YamaguchiShinozaki K (2012) NAC transcription factors in plant abiotic stress responses. Biochim Biophys Acta (BBA)-Gene Regul Mech 1819:97-103

Peleg Z, Saranga Y, Yazici A, Fahima T, Ozturk L, Cakmak I (2008) Grain zinc, iron and protein concentrations and zincefficiency in wild emmer wheat under contrasting irrigation regimes. Plant Soil 306:57-67

Ramakers C, Ruijter JM, Deprez RHL, Moorman AFM (2003) Assumption-free analysis of quantitative real-time polymerase chain reaction (PCR) data. Neurosci Lett 339:62-66

Shi R, Zhang Y, Chen X, Sun Q, Zhang F, Römheld V, Zou C (2010) Influence of long-term nitrogen fertilization on micronutrient density in grain of winter wheat (Triticum aestivum L.). J Cereal Sci 51:165-170

Simpson RJ, Lambers H, Dalling MJ (1983) Nitrogen redistribution during grain growth in wheat (Triticum aestivum L.): IV. Development of a quantitative model of the translocation of nitrogen to the grain. Plant Physiol 71:7-14

Snape JW, Foulkes MJ, Simmonds J, Leverington M, Fish LJ, Wang Y, Ciavarrella M (2007) Dissecting gene $x$ environmental effects on wheat yields via QTL and physiological analysis. Euphytica 154:401-408
Thomas H, Howarth CJ (2000) Five ways to stay green. J Exp Bot 51:329-337

Uauy C, Brevis JC, Dubcovsky J (2006a) The high grain protein content gene Gpc-B1 accelerates senescence and has pleiotropic effects on protein content in wheat. J Exp Bot 57:2785-2794

Uauy C, Distelfeld A, Fahima T, Blechl A, Dubcovsky J (2006b) A NAC gene regulating senescence improves grain protein, zinc, and iron content in wheat. Science 314:1298-1301

Van der Graaff E, Schwacke R, Schneider A, Desimone M, Flugge UI, Kunze R (2006) Transcription analysis of Arabidopsis membrane transporters and hormone pathways during developmental and induced leaf senescence. Plant Physiol 141:776-792

Van Sanford DA, MacKown CT (1987) Cultivar differences in nitrogen remobilization during grain fill in soft red winter wheat. Crop Sci 27:295-300

Waters BM, Grusak MA (2008) Whole-plant mineral partitioning throughout the life cycle in Arabidopsis thaliana ecotypes Columbia, Landsberg erecta, Cape Verde Islands, and the mutant line ysl1ysl3. New Phytol 177:389-405

Waters BM, Sankaran RP (2011) Moving micronutrients from the soil to the seeds: Genes and physiological processes from a biofortification perspective. Plant Sci 180:562-574

Waters BM, Uauy C, Dubcovsky J, Grusak MA (2009) Wheat (Triticum aestivum) NAM proteins regulate the translocation of iron, zinc, and nitrogen compounds from vegetative tissues to grain. J Exp Bot 60:4263-4274

Welch RM, Graham RD (2004) Breeding for micronutrients in staple food crops from a human nutrition perspective. J Exp Bot 55:353-364

Xue G-P, Way HM, Richardson T, Drenth J, Joyce PA, McIntyre CL (2011) Overexpression of TaNAC69 leads to enhanced transcript levels of stress up-regulated genes and dehydration tolerance in bread wheat. Mol Plant 4:697-712

Zheng HJ, Wu AZ, Zheng CC, Wang YF, Cai R, Shen XF, Xu RR, Liu P, Kong LJ, Dong ST (2009) QTL mapping of maize (Zea mays) stay-green traits and their relationship to yield. Plant Breed 128:54-62

Zhu L, Liang ZS, Xu X, Li SH (2008) Relationship between carbon isotope discrimination and mineral content in wheat grown under three different water regimes. J Agron Crop Sci 194:421-428 
Supplemental resource 1. Effect of genotype, TaNAM-RNAi or Wild-type (WT), on mineral concentrations in vegetative tissue and contents in vegetative tissue and seeds of plants grown in two greenhouse fertility studies. Data are means over fertility treatments. ANOVA was used to test significance of genotype effects.

\begin{tabular}{|c|c|c|c|c|}
\hline \multirow[b]{3}{*}{ Mineral } & \multicolumn{4}{|c|}{ Concentration in Vegetative Tissue at Anthesis $\left(\mu \mathrm{g} \mathrm{g}^{-1}\right)$} \\
\hline & \multicolumn{2}{|c|}{ Heat Stress Environment } & \multicolumn{2}{|c|}{ Optimal Temperature Environment } \\
\hline & TaNAM-RNAi & WT & TaNAM-RNAi & WT \\
\hline $\mathrm{Mg}$ & $2320 \pm 60$ & $2370 \pm 60$ & $2145 \pm 56$ & $2007 \pm 56$ \\
\hline $\mathbf{P}$ & $1480 \pm 34.3$ & $1550 \pm 34.3$ & $2708 \pm 84$ & $2703 \pm 84$ \\
\hline$S$ & $2330 \pm 110$ & $2380 \pm 110$ & $3259 \pm 99$ & $3000 \pm 99$ \\
\hline K & $31000 \pm 520$ & $31400 \pm 520$ & $41807 \pm 882$ & $39965 \pm 882$ \\
\hline $\mathrm{Ca}$ & $5390 \pm 140$ & $5590 \pm 140$ & $5990 \pm 205$ & $5212 \pm 205$ \\
\hline $\mathrm{Mn}$ & $63.7 \pm 2.6$ & $62.1 \pm 2.6$ & $87.2 \pm 3.2$ & $80.5 \pm 3.2$ \\
\hline Fe & $53.5 \pm 5.5$ & $68.6 \pm 5.5$ & $56.3 \pm 1.7$ & $58.7 \pm 1.7$ \\
\hline $\mathrm{Cu}$ & $9.05 \pm 1.07$ & $8.79 \pm 1.07$ & $5.44 \pm 0.25$ & $4.82 \pm 0.25$ \\
\hline $\mathrm{Zn}$ & $23.0 \pm 1.22$ & $21.4 \pm 1.22$ & $27.2 \pm 1.1$ & $24.1 \pm 1.1$ \\
\hline Mo & $1.96 \pm 0.08$ & $2.03 \pm 0.08$ & $0.772 \pm 0.086$ & $0.917 \pm 0.086$ \\
\hline \multirow[t]{4}{*}{ Cd } & $0.310 \pm 0.015$ & $0.318 \pm 0.015$ & $0.371 \pm 0.030$ & $0.388 \pm 0.030$ \\
\hline & \multicolumn{4}{|c|}{ Concentration in Vegetative Tissue at Maturity $\left(\mu \mathrm{g} \mathrm{g}^{-1}\right)$} \\
\hline & \multicolumn{2}{|c|}{ Heat Stress Environment } & \multicolumn{2}{|c|}{ Optimal Temperature Environment } \\
\hline & TaNAM-RNAi & WT & TaNAM-RNAi & WT \\
\hline $\mathrm{Mg}$ & $3130 \pm 80$ & $2970 \pm 70$ & $2217 \pm 65$ & $2038 \pm 70$ \\
\hline $\mathbf{P}$ & $1240 \pm 70$ & $1330 \pm 70$ & $1148 \pm 72$ & $789 \pm 78^{* *}$ \\
\hline $\mathbf{S}$ & $4760 \pm 150$ & $4140 \pm 140 * *$ & $3682 \pm 108$ & $3124 \pm 116^{* *}$ \\
\hline K & $24000 \pm 800$ & $25000 \pm 800$ & $33438 \pm 879$ & $38860 \pm 942 * *$ \\
\hline $\mathrm{Ca}$ & $8280 \pm 260$ & $7610 \pm 250$ & $6686 \pm 250$ & $6571 \pm 270$ \\
\hline$M n$ & $90.4 \pm 5.0$ & $94.1 \pm 4.8$ & $111 \pm 6$ & $99.3 \pm 6.0$ \\
\hline Fe & $37.6 \pm 1.1$ & $36.0 \pm 1.0$ & $54.7 \pm 13.2$ & $56.7 \pm 14.2$ \\
\hline $\mathrm{Cu}$ & $6.91 \pm 0.20$ & $6.99 \pm 0.19$ & $6.54 \pm 0.26$ & $4.60 \pm 0.28 * *$ \\
\hline $\mathbf{Z n}$ & $17.9 \pm 1.0$ & $14.8 \pm 0.9$ & $11.1 \pm 0.8$ & $7.1 \pm 0.8^{* *}$ \\
\hline Mo & $2.82 \pm 0.13$ & $3.11 \pm 0.12$ & $1.95 \pm 0.08$ & $1.71 \pm 0.09 *$ \\
\hline Cd & $0.442 \pm 0.022$ & $0.481 \pm 0.021$ & $0.555 \pm 0.032$ & $0.480 \pm 0.034$ \\
\hline
\end{tabular}


Supplemental resource 1, continued

\begin{tabular}{|c|c|c|c|c|}
\hline & \multicolumn{4}{|c|}{ Content in Vegetative Tissue at Anthesis $\left(\mu \mathrm{g} \mathrm{plant}^{-1}\right)$} \\
\hline & \multicolumn{2}{|c|}{ Heat Stress Environment } & \multicolumn{2}{|c|}{ Optimal Temperature Environment } \\
\hline Mineral & TaNAM-RNAi & WT & TaNAM-RNAi & WT \\
\hline Mg & $2190 \pm 120$ & $1990 \pm 120$ & $6182 \pm 336$ & $4651 \pm 336 * *$ \\
\hline $\mathbf{P}$ & $1400 \pm 70$ & $1290 \pm 70$ & $7925 \pm 533$ & $6314 \pm 533 *$ \\
\hline $\mathbf{S}$ & $2210 \pm 140$ & $2000 \pm 140$ & $9383 \pm 496$ & $6970 \pm 496 * *$ \\
\hline K & $29200 \pm 1300$ & $26200 \pm 1300$ & $120590 \pm 4690$ & $93030 \pm 4390 * *$ \\
\hline $\mathrm{Ca}$ & $5080 \pm 280$ & $4700 \pm 280$ & $17318 \pm 934$ & $11976 \pm 934 * *$ \\
\hline $\mathrm{Mn}$ & $60.2 \pm 3.6$ & $52.0 \pm 3.6$ & $251 \pm 13$ & $185 \pm 13^{* *}$ \\
\hline $\mathrm{Fe}$ & $50.1 \pm 4.6$ & $57.5 \pm 4.6$ & $162 \pm 9$ & $136 \pm 9$ \\
\hline $\mathrm{Cu}$ & $8.31 \pm 0.94$ & $7.40 \pm 0.94$ & $16.0 \pm 1.2$ & $11.2 \pm 1.2 * *$ \\
\hline $\mathrm{Zn}$ & $21.6 \pm 1.5$ & $18.2 \pm 1.5$ & $78.8 \pm 4.9$ & $56.1 \pm 4.9^{* *}$ \\
\hline Mo & $1.88 \pm 0.12$ & $1.68 \pm 0.11$ & $2.22 \pm 0.26$ & $2.09 \pm 0.26$ \\
\hline \multirow[t]{4}{*}{ Cd } & $0.290 \pm 0.020$ & $0.269 \pm 0.020$ & $1.070 \pm 0.075$ & $0.875 \pm 0.075$ \\
\hline & \multicolumn{4}{|c|}{ Content in Vegetative Tissue at Maturity ( $\mathrm{gg} \mathrm{plant}^{-1}$ ) } \\
\hline & \multicolumn{2}{|c|}{ Heat Stress Environment } & \multicolumn{2}{|c|}{ Optimal Temperature Environment } \\
\hline & TaNAM-RNAi & WT & TaNAM-RNAi & WT \\
\hline $\mathrm{Mg}$ & $4150 \pm 155$ & $2880 \pm 149 * *$ & $10137 \pm 349$ & $6627 \pm 374^{* *}$ \\
\hline $\mathbf{P}$ & $1640 \pm 85$ & $1260 \pm 82^{* *}$ & $5472 \pm 390$ & $2739 \pm 419 * *$ \\
\hline $\mathbf{S}$ & $6300 \pm 240$ & $3950 \pm 233^{* *}$ & $17206 \pm 676$ & $10349 \pm 726^{* *}$ \\
\hline $\mathbf{K}$ & $31400 \pm 1240$ & $24000 \pm 1220^{* *}$ & $154883 \pm 4605$ & $129110 \pm 4605^{* *}$ \\
\hline $\mathrm{Ca}$ & $10900 \pm 417$ & $7330 \pm 403^{* *}$ & $30541 \pm 1201$ & $21432 \pm 1277^{* *}$ \\
\hline$M n$ & $117 \pm 7$ & $92.5 \pm 6.3^{* *}$ & $504 \pm 26$ & $323 \pm 28^{* *}$ \\
\hline $\mathrm{Fe}$ & $49.8 \pm 1.8$ & $34.6 \pm 1.7^{* *}$ & $257 \pm 42$ & $178 \pm 45$ \\
\hline $\mathrm{Cu}$ & $9.21 \pm 0.39$ & $6.78 \pm 0.38 * *$ & $30.3 \pm 1.4$ & $15.1 \pm 1.5^{* *}$ \\
\hline $\mathrm{Zn}$ & $20.4 \pm 1.0$ & $14.0 \pm 0.9 * *$ & $50.4 \pm 3.5$ & $24.5 \pm 3.8^{* *}$ \\
\hline Mo & $3.73 \pm 0.20$ & $3.08 \pm 0.20^{*}$ & $9.00 \pm 0.43$ & $5.59 \pm 0.46^{* *}$ \\
\hline \multirow[t]{4}{*}{ Cd } & $0.621 \pm 0.029$ & $0.465 \pm 0.028^{* *}$ & $2.50 \pm 0.14$ & $1.57 \pm 0.14^{* *}$ \\
\hline & \multicolumn{4}{|c|}{ Content in Seed at Maturity ( $\mu \mathrm{g} \mathrm{plant}^{-1}$ ) } \\
\hline & \multicolumn{2}{|c|}{ Heat Stress Environment } & \multicolumn{2}{|c|}{ Optimal Temperature Environment } \\
\hline & TaNAM-RNAi & WT & TaNAM-RNAi & WT \\
\hline $\mathrm{Mg}$ & $955 \pm 40$ & $935 \pm 38$ & $5924 \pm 278$ & $4935 \pm 298 * *$ \\
\hline $\mathbf{P}$ & $2300 \pm 107$ & $2450 \pm 103$ & $14878 \pm 724$ & $12363 \pm 777^{* *}$ \\
\hline $\mathbf{S}$ & $1150 \pm 52$ & $1180 \pm 51$ & $8053 \pm 381$ & $7055 \pm 409^{*}$ \\
\hline K & $3720 \pm 148$ & $2790 \pm 144 * *$ & $27802 \pm 1215$ & $17637 \pm 1292^{* *}$ \\
\hline $\mathrm{Ca}$ & $387 \pm 18$ & $322 \pm 17^{*}$ & $2661 \pm 131$ & $2050 \pm 140^{* *}$ \\
\hline $\mathrm{Mn}$ & $31.9 \pm 1.5$ & $32.4 \pm 1.4$ & $195 \pm 10$ & $172 \pm 11$ \\
\hline $\mathrm{Fe}$ & $24.4 \pm 1.5$ & $30.7 \pm 1.4^{* *}$ & $134 \pm 8$ & $137 \pm 8$ \\
\hline $\mathrm{Cu}$ & $2.87 \pm 0.14$ & $3.07 \pm 0.14$ & $14.4 \pm 1.4$ & $15.1 \pm 1.5$ \\
\hline $\mathrm{Zn}$ & $34.2 \pm 1.7$ & $35.3 \pm 1.7$ & $131 \pm 6$ & $113 \pm 7^{*}$ \\
\hline Mo & $0.635 \pm 0.042$ & $0.802 \pm 0.040^{* *}$ & $3.19 \pm 0.21$ & $3.45 \pm 0.22$ \\
\hline $\mathrm{Cd}$ & $0.114 \pm 0.008$ & $0.140 \pm 0.008^{*}$ & $0.751 \pm 0.053$ & $0.792 \pm 0.057$ \\
\hline
\end{tabular}

$*, * *$ indicate that F-value for genotype effect is significant at $p<0.05$ and 0.01 , respectively 
Supplemental resource 2. Normalized partitioning coefficient for minerals in two greenhouse fertility studies.

\begin{tabular}{|c|c|c|c|c|c|c|c|c|c|c|c|c|}
\hline \multicolumn{13}{|c|}{ Heat Stress Environment, } \\
\hline Genotype & $\begin{array}{l}\text { Fertility } \\
\left(\mathrm{mg} \mathrm{N} \mathrm{plant}^{-1}\right)\end{array}$ & Mg & $\mathbf{P}$ & $\mathbf{S}$ & $\mathbf{K}$ & $\mathrm{Ca}$ & Mn & $\mathrm{Fe}$ & $\mathrm{Cu}$ & $\mathrm{Zn}$ & Mo & $\mathrm{Cd}$ \\
\hline & 17.5 & 86.7 & 94.3 & 76.0 & 88.2 & 75.8 & 117.4 & 92.0 & 98.2 & 93.7 & 149.8 & 124.2 \\
\hline & 61.3 & 96.3 & 97.4 & 88.7 & 98.5 & 91.0 & 102.9 & 95.7 & 99.7 & 100.0 & 96.3 & 100.4 \\
\hline & 105 & 112.4 & 107.0 & 128.0 & 109.6 & 125.2 & 85.7 & 109.1 & 101.1 & 105.5 & 63.9 & 81.4 \\
\hline & & ${ }^{\star *}(1)^{\mathrm{a}}$ & $* *(1)$ & ${ }^{*}(2)$ & ${ }^{* *}(1)$ & $* \star(1)$ & $* *(1)$ & $* *(1)$ & ns & $* *(1)$ & $* *(1)$ & $* *(1)$ \\
\hline RNAi & 17.5 & 76.5 & 94.6 & 63.5 & 97.7 & 70.4 & 110.9 & 76.4 & 86.7 & 89.4 & 126.1 & 109.0 \\
\hline RNAi & 61.3 & 88.2 & 98.4 & 81.7 & 99.5 & 88.2 & 104.2 & 85.2 & 91.1 & 103.4 & 85.4 & 85.7 \\
\hline RNAi & 105 & 107.2 & 100.4 & 103.9 & 119.0 & 119.7 & 72.9 & 95.4 & 94.8 & 99.3 & 57.8 & 61.6 \\
\hline WT & 17.5 & 96.8 & 94.0 & 88.5 & 78.7 & 81.3 & 123.9 & 107.7 & 109.7 & 98.1 & 173.6 & 139.4 \\
\hline WT & 61.3 & 104.3 & 96.4 & 95.6 & 97.4 & 93.7 & 101.6 & 106.3 & 108.2 & 96.7 & 107.2 & 115.1 \\
\hline WT & 105 & 117.5 & 113.6 & 152.1 & 100.2 & 130.7 & 98.6 & 122.8 & 107.3 & 111.6 & 70.0 & 101.2 \\
\hline & & $n s^{b}$ & ns & $*(2)$ & ns & ns & ns & ns & ns & $*(2)$ & ns & ns \\
\hline
\end{tabular}

$*, * *$ indicate that F-value for effect is significant at $p<0.05$ and 0.01 , respectively; ns=non-significant

+Values in parentheses indicate order of response to fertilizer rate: 1=first-order (linear); 2=second-order (quadratic)

${ }^{\mathrm{a}}$ indicates response to $\mathrm{N}$ rate across genotypes

${ }^{\mathrm{b}}$ indicates whether response to $\mathrm{N}$ rate was different between genotypes 
Supplemental Resource 2 continued

\begin{tabular}{|c|c|c|c|c|c|c|c|c|c|c|c|c|}
\hline \multirow{2}{*}{\multicolumn{2}{|c|}{ 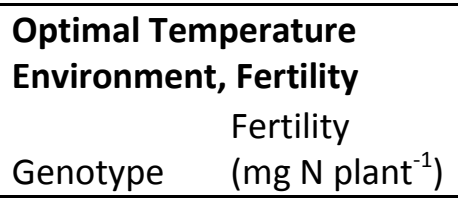 }} & \multicolumn{11}{|c|}{ Normalized Partitioning Coefficient } \\
\hline & & $\mathrm{Mg}$ & $\mathbf{P}$ & $\mathbf{S}$ & K & \multirow{2}{*}{$\begin{array}{c}\mathrm{Ca} \\
96.5\end{array}$} & \multirow{2}{*}{$\begin{array}{c}\text { Mn } \\
90.7\end{array}$} & \multirow{2}{*}{$\begin{array}{c}\mathrm{Fe} \\
92.5\end{array}$} & \multirow{2}{*}{$\begin{array}{c}\mathrm{Cu} \\
98.7\end{array}$} & \multirow{2}{*}{$\begin{array}{c}\text { Zn } \\
97.2\end{array}$} & \multirow{2}{*}{$\frac{\text { Mo }}{101.7}$} & $\mathrm{Cd}$ \\
\hline & 17.5 & 97.1 & 101.0 & 108.8 & 101.6 & & & & & & & 99.2 \\
\hline & 61.3 & 102.5 & 102.5 & 98.6 & 93.5 & 101.4 & 102.7 & 118.2 & 121.6 & 102.4 & 104.1 & 105.7 \\
\hline & 105 & 102.5 & 97.8 & 93.5 & 103.1 & 104.7 & 110.4 & 100.6 & 89.5 & 101.7 & 98.6 & 100.0 \\
\hline & & $\mathrm{ns}^{\mathrm{a}}$ & ns & $* *(1)^{\dagger}$ & $*(2)$ & ns & $* *(1)$ & $* *(2)$ & $* *(2)$ & ns & ns & ns \\
\hline RNAi & 17.5 & 95.9 & 99.1 & 99.3 & 121.3 & 102.7 & 90.9 & 92.8 & 88.4 & 95.1 & 90.6 & 88.0 \\
\hline RNAi & 61.3 & 92.5 & 97.2 & 85.3 & 101.7 & 90.7 & 87.5 & 86.4 & 89.8 & 95.5 & 83.6 & 80.5 \\
\hline RNAi & 105 & 99.9 & 96.2 & 88.9 & 117.7 & 105.5 & 103.8 & 81.0 & 75.1 & 100.5 & 83.5 & 88.6 \\
\hline WT & 17.5 & 98.3 & 102.8 & 118.4 & 81.9 & 90.4 & 90.5 & 92.1 & 109.0 & 99.3 & 112.7 & 110.3 \\
\hline WT & 61.3 & 112.5 & 107.8 & 111.8 & 85.3 & 112.1 & 117.9 & 150.1 & 153.3 & 109.4 & 124.5 & 130.8 \\
\hline WT & 105 & 105.2 & 99.4 & 98.1 & 88.4 & 103.8 & 116.9 & 120.3 & 103.8 & 103.0 & 113.8 & 111.4 \\
\hline & & $*(2)^{b}$ & ns & ns & ns & $* *(2)$ & $* *(2)$ & $* *(2)$ & $* *(2)$ & $*(2)$ & ns & $*(2)$ \\
\hline
\end{tabular}

$*, * *$ indicate that F-value for effect is significant at $p<0.05$ and 0.01 , respectively; ns=non-significant

†Values in parentheses indicate order of response to fertilizer rate: $1=$ first-order (linear); $2=$ second-order (quadratic)

${ }^{a}$ indicates response to $\mathrm{N}$ rate across genotypes

${ }^{\mathrm{b}}$ indicates whether response to $\mathrm{N}$ rate was different between genotypes 
Supplemental resource 3. Effect of genotype, TaNAM-RNAi or Wild-type (WT), and water limitation on mineral concentrations seed in two greenhouse irrigation studies.

\begin{tabular}{|c|c|c|c|c|c|c|c|c|c|c|c|c|c|}
\hline \multirow{2}{*}{\multicolumn{2}{|c|}{$\begin{array}{l}\text { Heat Stress } \\
\text { Environment, } \\
\text { Irrigation }\end{array}$}} & \multicolumn{12}{|c|}{ Concentration (ppm) } \\
\hline & & Mg & $\mathbf{P}$ & S & K & $\frac{\mathrm{Ca}}{505}$ & \multirow{2}{*}{$\frac{M n}{32.46}$} & \multirow{2}{*}{$\begin{array}{r}\text { Fe } \\
28.3\end{array}$} & $\mathrm{Cu}$ & $\mathrm{Zn}$ & Se & Mo & Cd \\
\hline RNAi & & 1311 & 3000 & 1809 & 5396 & 595 & & & 3.4 & 37.2 & 0.18 & 0.73 & 0.09 \\
\hline \multirow{5}{*}{ WT } & & 1369 & 3521 & 2036 & 4434 & 505 & 37.49 & 42.3 & 4.1 & 43.1 & 0.28 & 1.07 & 0.14 \\
\hline & & $n \mathrm{~s}^{\mathrm{a}}$ & $* *$ & $* *$ & $* *$ & $* *$ & $*$ & $* *$ & $* *$ & ns & $* *$ & $* *$ & $* *$ \\
\hline & 150 & 1191 & 2699 & 1792 & 4469 & 510 & 28.25 & 31.6 & 3.2 & 35.1 & 0.22 & 0.84 & 0.13 \\
\hline & 250 & 1489 & 3822 & 2053 & 5362 & 590 & 41.70 & 39.1 & 4.3 & 45.2 & 0.24 & 0.96 & 0.11 \\
\hline & & $* * \mathrm{~b}$ & $* *$ & $* *$ & $* *$ & $* *$ & $* *$ & $* *$ & $* *$ & $* *$ & ns & $*$ & $*$ \\
\hline RNAi & 150 & 1153 & 2454 & 1611 & 4664 & 548 & 26.05 & 25.8 & 2.9 & 33.0 & 0.17 & 0.71 & 0.11 \\
\hline RNAi & 250 & 1469 & 3547 & 2007 & 6128 & 643 & 38.87 & 30.8 & 4.0 & 41.4 & 0.19 & 0.76 & 0.08 \\
\hline WT & 150 & 1229 & 2945 & 1973 & 4273 & 473 & 30.45 & 37.3 & 3.5 & 37.1 & 0.27 & 0.98 & 0.16 \\
\hline \multirow[t]{2}{*}{ WT } & 250 & 1509 & 4097 & 2099 & 4595 & 536 & 44.53 & 47.4 & 4.7 & 49.0 & 0.29 & 1.16 & 0.13 \\
\hline & & $n s^{c}$ & ns & $* *$ & $* *$ & ns & ns & ns & ns & ns & ns & $\mathrm{ns}$ & ns \\
\hline
\end{tabular}

$*, * *$ indicate that F-value for effect is significant at $p<0.05$ and 0.01 , respectively; ns=non-significant

+Values in parentheses indicate order of response to fertilizer rate: 1=first-order (linear); 2=second-order (quadratic)

${ }^{a}$ indicates whether concentration was different between genotypes across water treatments

${ }^{b}$ indicates whether response to water treatment was significant across genotypes

${ }^{c}$ indicates whether response to water treatment was different between genotypes 
Supplemental resource 3 , continued

\begin{tabular}{|c|c|c|c|c|c|c|c|c|c|c|c|c|c|}
\hline \multicolumn{2}{|c|}{$\begin{array}{c}\text { Optimal } \\
\text { Temperature } \\
\text { Environment, } \\
\text { Irrigation }\end{array}$} & \multicolumn{12}{|c|}{ Concentration (ppm) } \\
\hline & & $\mathrm{Mg}$ & $\mathbf{P}$ & $S$ & K & $\mathrm{Ca}$ & Mn & $\mathrm{Fe}$ & $\mathrm{Cu}$ & $\mathrm{Zn}$ & Se & Mo & $\mathrm{Cd}$ \\
\hline RNAi & & 1419 & 3143 & 1978 & 6659 & 680.3 & 40.09 & 30.08 & 2.705 & 29.43 & 0.193 & 0.722 & 0.137 \\
\hline \multirow[t]{5}{*}{ WT } & & 1544 & 3787 & 2345 & 5917 & 651.9 & 46.42 & 44.41 & 3.625 & 33.64 & 0.23 & 0.983 & 0.189 \\
\hline & & $*^{\mathrm{a}}$ & $* *$ & $* *$ & $* *$ & ns & $* *$ & $* *$ & $* *$ & ns & $*$ & $* *$ & $* *$ \\
\hline & 150 & 1385 & 3258 & 2147 & 5985 & 605.4 & 38.05 & 39.37 & 3.525 & 34.19 & 0.218 & 0.842 & 0.155 \\
\hline & 250 & 1578 & 3671 & 2175 & 6591 & 726.9 & 48.45 & 35.12 & 2.805 & 28.88 & 0.205 & 0.864 & 0.171 \\
\hline & & $* * \mathrm{~b}$ & $*$ & ns & $* *$ & $* *$ & $* *$ & ns & $* *$ & ns & ns & ns & ns \\
\hline RNAi & 150 & 1281 & 2757 & 1896 & 6057 & 614.7 & 34.94 & 30.8 & 7.892 & 31.61 & 0.195 & 0.712 & 0.137 \\
\hline RNAi & 250 & 1557 & 3528 & 2059 & 7261 & 746 & 45.24 & 29.36 & 2.45 & 27.25 & 0.19 & 0.733 & 0.138 \\
\hline WT & 150 & 1489 & 3759 & 2399 & 5913 & 596.1 & 41.17 & 47.94 & 4.088 & 36.76 & 0.24 & 0.972 & 0.173 \\
\hline \multirow[t]{2}{*}{ WT } & 250 & 1599 & 3814 & 2290 & 5921 & 707.8 & 51.66 & 40.88 & 3.161 & 30.51 & 0.22 & 0.995 & 0.205 \\
\hline & & $\mathrm{ns}^{\mathrm{c}}$ & ns & ns & $* *$ & ns & ns & ns & ns & ns & ns & ns & ns \\
\hline
\end{tabular}

$*, * *$ indicate that F-value for effect is significant at $p<0.05$ and 0.01 , respectively; ns=non-significant

+Values in parentheses indicate order of response to fertilizer rate: 1=first-order (linear); 2=second-order (quadratic)

indicates whether concentration was different between genotypes across water treatments

${ }^{b}$ indicates whether response to water treatment was significant across genotypes

cindicates whether response to water treatment was different between genotypes 
Supplemental resource 4. Effect of genotype, TaNAM-RNAi or Wild-type (WT), and water limitation on seed mineral partitioning quotient in two greenhouse irrigation studies.

\begin{tabular}{|c|c|c|c|c|c|c|c|c|c|c|c|c|c|}
\hline \multicolumn{14}{|c|}{ Heat Stress } \\
\hline \multirow{2}{*}{\multicolumn{2}{|c|}{$\begin{array}{l}\text { Environment, } \\
\text { Irrigation }\end{array}$}} & \multicolumn{12}{|c|}{ Normalized Partioning Quotient } \\
\hline & & Mg & $\mathbf{P}$ & $\mathbf{S}$ & $\mathbf{K}$ & $\mathrm{Ca}$ & Mn & $\mathrm{Fe}$ & $\mathrm{Cu}$ & $\mathrm{Zn}$ & Se & Mo & Cd \\
\hline RNAi & & 97.8 & 98.0 & 89.2 & 118.9 & 106.0 & 96.3 & 81.2 & 88.4 & 96.8 & 78.7 & 88.1 & 83.8 \\
\hline \multirow[t]{5}{*}{ WT } & & 103.7 & 102.8 & 115.3 & 80.4 & 95.6 & 105.8 & 120.9 & 113.8 & 103.8 & 124.2 & 115.8 & 120.4 \\
\hline & & $n s^{a}$ & ns & $* *$ & $* *$ & ns & ns & $* *$ & $*$ & ns & $* *$ & $* *$ & $* *$ \\
\hline & 150 & 101.9 & 101.7 & 119.2 & 89.3 & 104.0 & 106.7 & 104.0 & 102.6 & 100.3 & 108.0 & 117.3 & 116.5 \\
\hline & 250 & 99.6 & 99.1 & 85.3 & 110.0 & 97.6 & 95.4 & 98.1 & 99.6 & 100.4 & 94.9 & 86.5 & 87.8 \\
\hline & & $n s^{b}$ & ns & $* *$ & $* *$ & ns & ns & ns & ns & ns & ns & $* *$ & $* *$ \\
\hline RNAi & 150 & 91.5 & 96.0 & 97.9 & 96.7 & 100.3 & 95.5 & 80.3 & 81.6 & 93.6 & 80.4 & 98.3 & 91.2 \\
\hline RNAi & 250 & 104.1 & 100.1 & 80.6 & 141.1 & 111.7 & 97.2 & 82.0 & 95.2 & 100.0 & 77.0 & 77.8 & 76.3 \\
\hline WT & 150 & 112.4 & 107.5 & 140.6 & 81.9 & 107.7 & 117.8 & 127.6 & 123.6 & 107.0 & 135.5 & 136.3 & 141.7 \\
\hline \multirow[t]{2}{*}{ WT } & 250 & 95.1 & 98.2 & 90.1 & 78.9 & 83.5 & 93.7 & 114.2 & 103.9 & 100.7 & 112.9 & 95.3 & 99.2 \\
\hline & & $* * \mathrm{c}$ & $*$ & $*$ & $* *$ & $* *$ & ns & $*$ & ns & ns & ns & ns & * \\
\hline
\end{tabular}

$*, * *$ indicate that F-value for effect is significant at $p<0.05$ and 0.01 , respectively; ns=non-significant

${ }^{a}$ indicates whether normalized partitioning quotient was different between genotypes across water treatments

${ }^{b}$ indicates whether response to water treatment was significant across genotypes

${ }^{c}$ indicates whether response to water treatment was different between genotypes 
Supplemental resource 4 , continued

\begin{tabular}{|c|c|c|c|c|c|c|c|c|c|c|c|c|c|}
\hline \multicolumn{14}{|c|}{$\begin{array}{l}\text { Optimal } \\
\text { Temperature }\end{array}$} \\
\hline \multicolumn{2}{|c|}{$\begin{array}{l}\text { Environment, } \\
\text { Irrigation }\end{array}$} & Mg & $\mathbf{P}$ & $\mathbf{S}$ & $\mathbf{K}$ & $\mathrm{Ca}$ & Mn & $\mathrm{Fe}$ & $\mathrm{Cu}$ & Zn & Se & Mo & $\mathrm{Cd}$ \\
\hline RNAi & & 94.0 & 96.8 & 88.2 & 106.4 & 97.9 & 92.1 & 78.2 & 73.5 & 97.8 & 85.6 & 87.4 & 88.3 \\
\hline \multirow[t]{5}{*}{ WT } & & 106.4 & 102.6 & 110.6 & 95.0 & 103.0 & 107.5 & 121.3 & 125.4 & 101.7 & 113.1 & 111.5 & 111.7 \\
\hline & & $* * \mathrm{a}$ & $* *$ & $* *$ & $*$ & ns & $* *$ & $* *$ & $* *$ & ns & $* *$ & $* *$ & $* *$ \\
\hline & 150 & 94.3 & 102.7 & 103.6 & 92.6 & 91.2 & 99.4 & 93.3 & 95.5 & 102.7 & 102.8 & 101.8 & 94.4 \\
\hline & 250 & 106.0 & 96.8 & 95.2 & 108.7 & 109.7 & 100.1 & 106.2 & 103.4 & 96.9 & 95.9 & 97.2 & 105.6 \\
\hline & & $* * b$ & $* *$ & $* *$ & $* *$ & $* *$ & ns & $*$ & ns & ns & ns & ns & $* *$ \\
\hline RNAi & 150 & 84.5 & 98.8 & 89.1 & 92.9 & 86.0 & 91.0 & 70.8 & 83.1 & 100.0 & 90.6 & 93.4 & 86.1 \\
\hline RNAi & 250 & 103.4 & 94.9 & 87.4 & 119.8 & 109.8 & 93.2 & 85.6 & 63.8 & 95.5 & 80.7 & 81.5 & 90.4 \\
\hline WT & 150 & 104.2 & 106.6 & 118.1 & 92.3 & 96.4 & 107.8 & 115.7 & 107.8 & 105.3 & 115.1 & 110.3 & 102.6 \\
\hline \multirow[t]{2}{*}{ WT } & 250 & 108.6 & 98.7 & 103.0 & 97.7 & 109.6 & 107.1 & 126.8 & 143.0 & 98.2 & 111.1 & 112.8 & 120.8 \\
\hline & & $n s^{c}$ & ns & $*$ & $*$ & ns & ns & ns & $* *$ & ns & ns & ns & $\mathrm{ns}$ \\
\hline
\end{tabular}

$*, * *$ indicate that F-value for effect is significant at $p<0.05$ and 0.01 , respectively; ns=non-significant

${ }^{\text {a }}$ indicates whether normalized partitioning quotient was different between genotypes across water treatments

${ }^{b}$ indicates whether response to water treatment was significant across genotypes

'indicates whether response to water treatment was different between genotypes 